\title{
THE OVERVIEW OF CURRENT EVIDENCE ON THE REPRODUCTIVE TOXICITY OF DIBUTYL PHTHALATE
}

\section{EWELINA CZUBACKA, SŁAWOMIR CZERCZAK, and MAŁGORZATA MIROSŁAWA KUPCZEWSKA-DOBECKA}

\author{
Nofer Institute of Occupational Medicine, Łódź, Poland
}

Department of Chemical Safety

\begin{abstract}
Over the past years, many legitimate concerns have been raised about the effects of dibutyl phthalate (DBP) as an endocrine disruptor, especially on reproduction. The aim of this publication is to critically review the literature related to the developmental and reproductive toxicity of DBP in animals. Several electronic databases were systematically searched until 2019. Studies were qualified for the review if they: linked exposure to DPB with reproduction, were published in English after 1990, and were conducted on animals. In the studies of the testicular effects of DBP on experimental animals, the most common effects of exposure included reduced fertility, atrophic changes in male gonads, degenerative changes in the epididymis, as well as a reduction in sperm count and motility, cryptorchidism, hypospadias, poor sperm quality and other genital defects (decreased testicular weight, delayed spermatogenesis, Leydig cell aggregation, impaired Sertoli cell maturation, and significant inhibitions of testicular enzymes). The embryotoxic effects of DBP on laboratory animals included mainly an increase in fetal resorption and a decrease in live births. The teratogenic effects of DBP also manifest as skeletal malformations in fetuses, malformations of male gonads and other genital effects. On the basis of the literature data, it is clearly demonstrated that DBP shows anti-androgenic effects; however, there are also reports confirming its weak estrogenic effect. Additionally, lower doses cause more adverse effects than the highest dose, which is an important fact because of the widespread environmental exposure to DBP. The studies clearly confirm that DBP is an endocrine disruptor. Int J Occup Med Environ Health. 2021;34(1):15-37
\end{abstract}

Key words:

reprotoxicity, toxicology, dibutyl phthalate, endocrine disruptor, embryotoxicity, teratogenicity

\section{INTRODUCTION}

Dibutyl phthalate (DBP; CAS 84-74-2) occurs as colorless to light yellow oily liquid with a weak odor characteristic of esters. It is used in industry as a plasticizer, in the synthesis of polymers, as a laboratory agent, in analytics, in the production of polyvinyl chloride items, in ceramics and propellants, as a solvent (e.g., in the production of maleic anhydride), and as a metal working fluid [1].
It is worth to mention that phthalates, when used in electrical and electronic equipment, e.g., in cables or capacitors, may have a negative impact on recycling, as well as on human health and the environment, primarily during the processing of this waste equipment [2]. In addition, approx. 8.4 million tons of plasticizers are produced globally every year, of which Europe produces approximately 1.5 million metric tons [3]. Another interesting fact is that

\footnotetext{
Funding: this study was supported by the Nofer Institute of Occupational Medicine (project No. IMP.24.20 entitled "Indication of the most common occupational chemical carcinogens and mutagens among women - spatial analysis of their occurrence and development of recommendations aiming to reduction of women's exposure underestimation," project manager: Agnieszka Niepsuj, M.Sc.) and by the Ministry of Science and Higher Education/National Center for Research and Development (fifth stage of the multi-annual program financed in 2020-2022 entitled "Improving safety and working conditions," program coordinator: Central Institute for Labor Protection - National Research Institute).

Received: May 8, 2020. Accepted: September 7, 2020.

Corresponding author: Ewelina Czubacka, Nofer Institute of Occupational Medicine, Department of Chemical Safety, Teresy 8, 91-348 Łódź, Poland (e-mail: Ewelina. Czubacka@imp.lodz.pl).
} 
DBP is manufactured in and/or imported to the European Economic Area in 1000-10 000 tons a year [4].

Dibutyl phthalate traded on the market is recognized by the European Chemicals Agency (ECHA) as a substance which can disrupt hormonal balance, referred to as an endocrine disrupting chemical or an endocrine disruptor [5]. An endocrine disruptor is defined as an "exogenous substance or mixture that alters function(s) of the endocrine system and consequently causes adverse health effects in an intact organism, or its progeny, or (sub)populations." Such substances can lead, among others, to fertility disorders, genital development disorders, hormone-dependent cancer (e.g., breast, prostate, ovary or testicle cancer), damage to the fetus (including its nervous system), and metabolism disorders [6].

In accordance with Annex XVII of Regulation (EC) No. 1907/2006 of the European Parliament and of the Council concerning the Registration, Evaluation, Authorisation and Restriction of Chemicals (REACH Regulation), establishing the European Chemicals Agency, amending Directive 1999/45/EC and repealing Council Regulation (EEC) No. 793/93 and Commission Regulation (EC) No. 1488/94, as well as Council Directive 76/769/EEC and Commission Directives 91/155/EEC, 93/67/EEC, 93/105/EC and 2000/21/EC [7], the possibilities of using phthalates are very limited.

In accordance with Regulation (EC) No. 1272/2008 of the European Parliament and of the Council on classification, labelling and packaging of substances and mixtures, amending and repealing Directive 67/548/EEC and 1999/45/EC, and amending Regulation (EC) 1907/2006 (CLP Regulation) and amending Regulation (EC) No. 1907/2006 [8], DBP has the assigned reproductive toxicity category $1 \mathrm{~B}$ (Repr. 1B) and aquatic acute category 1 (Aquatic acute 1).

The aim of this study is to summarize and analyze literature data related to DBP and its effect on reproduction and development in animals. As previous reviews which focused on this matter were performed in 1999-2014 [9-12], there is a need to reevaluate and assess the new data on DBP and its effect on reproduction.

\section{METHODS}

The literature review was performed on the basis of the Internet databases of peer-reviewed scientific journals, including EBSCO Discovery Service, Science Direct, Scopus, PubMed and MEDLINE, as well as data available on ECHA and European Commission's websites. In the preparation of this study, papers published in 19902019, only in English, were considered. Relevant studies were also identified through a review of the references cited in all the published studies. Studies where DBP was used in combination with other phthalates or other substances, or examining other outcomes, were excluded. Only original articles were included.

In the preparation of this study, the following keywords: "dibutyl phthalate application" (75 articles found, 14 excluded), "dibutyl phthalate reprotoxicity" (156 articles found, 53 excluded) "dibutyl phthalate embryotoxicity" (245 articles found, 122 articles excluded), and "dibutyl phthalate teratogenicity" (229 articles found, 115 excluded) were used. In total, 401 articles were initially retrieved. Excluded articles were unrelated $(\mathrm{N}=217)$, inaccessible $(\mathrm{N}=23)$ or duplicate $(\mathrm{N}=64)$. Finally, this review included animal studies published in English, in peer-reviewed journals, since 1990. This period was chosen because a growing body of literature providing data on the reproductive toxicity of DBP and using different methods was published. So, there is a need to reevaluate both older and new data on this topic. Abstracts of the remaining articles were read in search of the adverse effects of DBP on the reproductive system in laboratory animals.

\section{RESULTS}

\section{Reprotoxicity - testicular effects}

Data on the effects of DBP action on reproduction, which manifest on the testes of treated animals, are presented in 
Table 1 (16 studies: 11 on rats, 2 on rabbits, 2 on mice, 1 on monkeys) [13-27]. The table is divided by animal species (rats, mice, rabbits, monkeys) and exposure time (shorttime exposure - up to 28 days: 12 studies, and sub-chronic exposure - up to 13 weeks: 4 studies).

Mice treated with DBP orally at the lowest doses (1-10 mg/kg bw) had a reduced anogenital distance and testicular weight with delayed spermatogenesis, which is directly related to impaired and reduced Sertoli cells proliferation/maturation [24]. Delayed spermatogenesis seems to appear in mice in a much lower dose ( $\geq 1 \mathrm{mg} / \mathrm{kg}$ bw) [24] than in rats $(\geq 250 \mathrm{mg} / \mathrm{kg} \mathrm{bw})$ [17]. In addition, the late onset of certain toxic effects in rats may also be related to the conditions under which the experiment was conducted (the route of administration and the duration of exposure). The most sensitive species, in terms of the reprotoxic effects of DBP, are mice. Some authors have concluded that male reproductive toxicity occurs through mechanisms related to these corresponding with oxidative stress [16,20,21].

A higher dose in rats $(31 \mathrm{mg} / \mathrm{kg}$ bw) caused testicular atrophy and increased sperm abnormalities [19]. The rodents treated with DBP doses of $>100 \mathrm{mg} / \mathrm{kg}$ bw (rats) or $163 \mathrm{mg} / \mathrm{kg}$ bw (mice) had a reduced sperm count and quality, with abnormal morphology of the seminiferous tubules $[18,19]$. Additionally, an increase in the serum testosterone level was observed in the mice which received DBP via food [23].

In the subsequent dose range (200-250 mg/kg bw), in addition to the symptoms listed above, decreased sperm motility, significant changes in testicular enzymes, defective spermatogenesis and shrunken tubules were observed in rats receiving DBP orally $[15,17,20]$.

Treating rats with DBP at a dose of $359 \mathrm{mg} / \mathrm{kg}$ bw/day for 13 weeks via food resulted in a lower body weight gain [23]. During short-term exposure (15 days), in the Wistar rats receiving a higher dose of DBP (400 $\mathrm{mg} / \mathrm{kg}$ bw/day) via gavage, degeneration and even absence of spermatogenesis occurred in most of the seminiferous tubules [16].
In the rabbits treated with DBP at a dose of $400 \mathrm{mg} / \mathrm{kg}$ bw/day (given via gavage for 8 weeks) increased liver weight, degeneration and atrophy of the seminiferous tubules, disintegration and shed of the seminiferous epithelial cells, changes in testicular enzyme levels, and in serum testosterone and androgen levels, were observed [26]. A lower serum testosterone level, and decreased prostate and testicular weights, were noticed in the rabbits receiving DBP orally at a dose of $520 \mathrm{mg} / \mathrm{kg}$ bw/day [25]. Abnormal sperm count was doubled in the lower dose; however, the rabbits exposed to the higher dose had a decreased sperm count. In the rabbits treated with DBP at a dose of $400 \mathrm{mg} / \mathrm{kg}$ bw/day, the epididymal sperm count did not change whereas a lower dose ( $\geq 100 \mathrm{mg} / \mathrm{kg}$ bw/day) in rodents caused adverse effects on sperm production $[15,18,19]$. Administering DBP at a dose of $520 \mathrm{mg} / \mathrm{kg}$ bw resulted in a decreased progressive and mass sperm motility and live sperm percentage, along with a significant elevation of testicular malondialdehyde, and without changes in other testicular enzymes. Finally, a decreased sperm count was observed. At this dose, the nonreproductive organs weight did not change, as was observed in the rodents receiving a lower dose $[19,21]$.

When given orally at a dose of $500 \mathrm{mg} / \mathrm{kg}$ bw/day, DBP caused subsequent toxic effects in rodents, which are described in detail in Table $1[15,17,21,24]$. However, Mitsuhashi et al. [19] found no changes in the serum and testicular testosterone levels despite the use $500 \mathrm{mg} / \mathrm{kg}$ bw of DBP in rats.

In the Wistar rats treated with DBP at a dose of $600 \mathrm{mg} / \mathrm{kg} \mathrm{bw} /$ day (via gavage for 15 days), necrosis of the seminiferous tubules was observed [16].

Increasing the dose to $720 \mathrm{mg} / \mathrm{kg}$ bw/day (via food) and extending the exposure time to 13 weeks in F344 rats induced focal atrophy of the seminiferous tubules and degeneration of the germinal epithelium [23].

The mice given $812 \mathrm{mg} / \mathrm{kg}$ bw/day of DBP via food for 13 weeks showed increased zinc concentrations in the testes [23]. 
Table 1. The effects of dibutyl phthalate (DBP) on male animal reproduction - short-term and sub-chronic exposure

\begin{tabular}{|c|c|c|}
\hline Study data & Results & Reference \\
\hline \multicolumn{3}{|l|}{$\begin{array}{l}\text { Rats } \\
\text { short-term exposure }\end{array}$} \\
\hline $\begin{array}{l}\text { Sprague Dawley rats (males - lack } \\
\text { of data, } 5-14 \text { days old); DBP was } \\
\text { given subcutaneously in corn oil; } \\
\text { doses: } 0,5,10,20 \mathrm{mg} / \mathrm{animal} \\
(0,250,500,1000 \mathrm{mg} / \mathrm{kg} \mathrm{bw}) \\
\text { for } 9 \text { consecutive days (examination } \\
\text { after } 17 \text { and } 28 \text { days of treatment); } \\
\text { the animals were killed on day } 24 \\
\text { or } 31 \text { of their life }\end{array}$ & $\begin{array}{l}\text { - } 1000 \mathrm{mg} / \mathrm{kg} \text { bw/day } \\
\text { ○ significantly reduced body weight (day } 15-17) \\
\circ \text { decreased testicular weight and seminal vesicles (day } 28) \\
\circ \text { mild hyperplasia of Leydig cells in the seminiferous tubules } \\
\text { (day } 17) \\
\text { O presence of multinuclear germ cells } \\
\text { - NOAEL } 500 \mathrm{mg} / \mathrm{kg} \mathrm{bw} / \text { day }\end{array}$ & 13 \\
\hline $\begin{array}{l}\text { Wistar rats ( } 10 \text { males, } 10 \text { weeks old); } \\
\text { DBP was given orally via gavage } \\
\text { in corn oil; doses: } 0,2000 \mathrm{mg} / \mathrm{kg} \text { bw } \\
\text { for } 9 \text { consecutive days; the animals } \\
\text { were killed } 24 \mathrm{~h} \text { after the last } \\
\text { treatment }\end{array}$ & $\begin{array}{l}\text { - } 2000 \mathrm{mg} / \mathrm{kg} \text { bw/day } \\
\text { ○ decreased body weight gain } \\
\text { ○ decreased spermatozoa motility }(66 \%) \\
\text { ○ slightly decreased sperm count } \\
\text { ○ increase in abnormal spermatozoa }(77 \%) \\
\text { ○ decreased relative testicular weight } \\
\text { ○ increased activity of the marker enzymes of oxidative stress } \\
\text { ○ degeneration of the seminiferous tubules } \\
\text { o defoliation and necrosis of spermatocytes }\end{array}$ & 14 \\
\hline $\begin{array}{l}\text { Sprague-Dawley rats } \\
\text { (10 males/group); DBP was given } \\
\text { orally via gavage in corn oil; doses: } \\
0,100,250,500 \mathrm{mg} / \mathrm{kg} \text { bw/day } \\
\text { for } 2 \text { weeks; the animals were killed } \\
\text { at the end of treatment }\end{array}$ & $\begin{aligned} &- \geq 250 \mathrm{mg} / \mathrm{kg} \text { bw/day } \\
& \circ \text { decreased sperm and count motility } \\
& \circ \text { significant inhibition of the superoxide dismutase, glutathione } \\
& \text { peroxidase and glutathione in the testes } \\
& \circ \text { increased level of malondialdehyde in the testes } \\
&-500 \mathrm{mg} / \mathrm{kg} \text { bw/day } \\
& \circ \text { decreased body weight and testicular weight } \\
& \circ \text { disintegration and shed of the seminiferous epithelial cells } \\
& \bigcirc \text { atrophy of the seminiferous tubules }\end{aligned}$ & 15 \\
\hline $\begin{array}{l}\text { Wistar rats ( } 24 \text { males); DBP was } \\
\text { given orally via gavage in corn oil; } \\
\text { doses: } 200,400,600 \mathrm{mg} / \mathrm{kg} \text { bw/day } \\
\text { for } 15 \text { days }\end{array}$ & $\begin{array}{l}-\quad \geq 200 \mathrm{mg} / \mathrm{kg} \text { bw/day } \\
\circ \text { decreased testicular weight, sperm and count motility } \\
\circ \text { decreased testosterone and FSH level } \\
\circ \text { decreased testicular lactate dehydrogenase activity } \\
\circ \text { decreased testicular antioxidant enzyme levels and serum total } \\
\text { antioxidant capacity } \\
\circ \text { degenerative changes in the testes } \\
\circ \text { absence of sperm in some seminiferous tubules } \\
\text { - }>400 \mathrm{mg} / \mathrm{kg} \text { bw/day } \\
\circ \text { degeneration and absence of spermatogenesis in most seminiferous } \\
\text { tubules } \\
-600 \mathrm{mg} / \mathrm{kg} \text { bw/day } \\
\text { ○ necrosis of some seminiferous tubules }\end{array}$ & 16 \\
\hline
\end{tabular}


Table 1. The effects of dibutyl phatalate (DBP) on male animal reproduction - short-term and sub-chronic exposure - cont.

\begin{tabular}{|c|c|c|}
\hline Study data & Results & Reference \\
\hline \multicolumn{3}{|l|}{$\begin{array}{l}\text { Rats - cont. } \\
\text { short-term exposure - cont. }\end{array}$} \\
\hline $\begin{array}{l}\text { Wistar rats (6 males/group, } \\
5 \text { weeks old); DBP was given orally } \\
\text { in ground-nut oil; doses: } 250,500 \\
\text { and } 1000 \mathrm{mg} / \mathrm{kg} \text { bw for } 15 \text { consecutive } \\
\text { days; the animals were killed } \\
\text { on day } 16\end{array}$ & $\begin{array}{l}\text { - } 250 \mathrm{mg} / \mathrm{kg} \mathrm{bw} / \text { day } \\
\circ \text { shrunken tubules and defective spermatogenesis } \\
\text { - } \geq 500 \mathrm{mg} / \mathrm{kg} \text { bw/day } \\
\circ \text { decreased testicular weight } \\
\circ \text { marked degeneration of the seminiferous tubules } \\
\circ \text { decreased acid phosphatase and sorbitol dehydrogenase levels } \\
\circ \text { increased lactate dehydrogenase level } \\
\circ \text { increased glucose- } 6 \text {-phosphate dehydrogenase, } \gamma \text {-glutamyl } \\
\text { transpeptidase and } \beta \text {-glucuronidase levels }\end{array}$ & 17 \\
\hline $\begin{array}{l}\text { Sprague-Dawley rats } \\
\text { ( } 20 \mathrm{males} / \text { group); DBP was given } \\
\text { orally via gavage; doses: } 0,100,250 \text {, } \\
500 \mathrm{mg} / \mathrm{kg} / \text { day for } 21 \text { consecutive } \\
\text { days; the animals were killed } 24 \mathrm{~h} \\
\text { after the last treatment }\end{array}$ & $\begin{array}{l}-\geq 100 \mathrm{mg} / \mathrm{kg} / \text { day } \\
\circ \text { abnormal morphology of the seminiferous tubules } \\
\circ \text { reduced sperm quality } \\
\circ \text { heteromorphosis of the mitochondrion and nucleus in the spermatic } \\
\text { or spermatogonial cell }\end{array}$ & 18 \\
\hline $\begin{array}{l}\text { F344 rats ( } 9 \text { males/group, } 10 \text { weeks } \\
\text { old); DBP was given orally in corn oil; } \\
\text { doses: } 0,31.25,125,500 \mathrm{mg} / \mathrm{kg} \text { bw/day } \\
\text { for } 4 \text { weeks }\end{array}$ & $\begin{array}{l}\text { - } 31.25 \mathrm{mg} / \mathrm{kg} \mathrm{bw} / \text { day } \\
\text { ○ increased sperm abnormalities } \\
\circ \text { testicular atrophy } \\
\text { - } 125 \mathrm{mg} / \mathrm{kg} \text { bw/day } \\
\text { ○ increased relative liver and kidneys weight } \\
\circ \text { decreased sperm count } \\
\text { - } 500 \mathrm{mg} / \mathrm{kg} \mathrm{bw} / \text { day } \\
\text { ○ decreased body weight gain } \\
\text { ○ serum and testicular testosterone level within the normal range } \\
\text { - LOAEL } 31.25 \mathrm{mg} / \mathrm{kg} \mathrm{bw/day}\end{array}$ & 19 \\
\hline $\begin{array}{l}\text { Sprague-Dawley rats (males); } \\
\text { DBP was given orally; dose: } \\
250 \mathrm{mg} / \mathrm{kg} \text { bw/day for } 4,8 \text { or } 12 \text { weeks }\end{array}$ & $\begin{array}{l}\text { - } 250 \mathrm{mg} / \mathrm{kg} \text { bw/day } \\
\text { ○ decreased sperm count } \\
\text { ○ increased production of abnormal sperm } \\
\text { ○ Sertoli cells vacuolization at the longest treatment } \\
\text { ○ changes in the serum testosterone level } \\
\text { ○ irregular arrangements of the seminiferous tubules } \\
\text { ○ decreased glutathione peroxidase and superoxide dismuase levels }\end{array}$ & 20 \\
\hline $\begin{array}{l}\text { Sprague-Dawley rats ( } 6 \text { males/group); } \\
\text { DBP was given orally via gavage; } \\
\text { dose: } 500 \mathrm{mg} / \mathrm{kg} \text { bw/day for } 4 \text { weeks }\end{array}$ & $\begin{array}{l}\text { - } 500 \mathrm{mg} / \mathrm{kg} \mathrm{bw} / \text { day } \\
\text { ○ increased liver weight } \\
\circ \text { decreased testicular weight } \\
\text { ○ decreased sperm count and motility }\end{array}$ & 21 \\
\hline $\begin{array}{l}\text { F344 rats ( } 5 \text { males/group, } 6 \text { weeks } \\
\text { old); DBP was given via food; } \\
\text { doses: } 0,61,225,1535 \mathrm{mg} / \mathrm{kg} \text { bw/day } \\
\text { for } 28 \text { days }\end{array}$ & $\begin{array}{l}\text { - } 1535 \mathrm{mg} / \mathrm{kg} \mathrm{bw} / \mathrm{day} \\
\text { ○ degeneration of the seminiferous tubules } \\
\circ \text { diminished spermatogenesis } \\
\text { ○ prominent vacuolization of spermatogonia } \\
\text { ○ morphological changes in sperm } \\
\text { - }\end{array}$ & 22 \\
\hline
\end{tabular}


Table 1. The effects of dibutyl phthalate (DBP) on male animal reproduction - short-term and sub-chronic exposure - cont.

\begin{tabular}{|c|c|c|}
\hline Study data & Results & Reference \\
\hline \multicolumn{3}{|l|}{$\begin{array}{l}\text { Rats - cont. } \\
\text { sub-chronic exposure }\end{array}$} \\
\hline $\begin{array}{l}\text { F344 rats (10 males/group, } \\
\text { 29-30 weeks old); DBP was given } \\
\text { via food: } 0 \%, 0.25 \%, 0.5 \%, 1.0 \% \text {, } \\
\text { 2.0\%, } 4.0 \% \text { (average: } 0,176,359 \\
720,1540,2964 \mathrm{mg} / \mathrm{kg} \text { bw } / \text { day) } \\
\text { for } 13 \text { weeks }\end{array}$ & $\begin{array}{l}\text { - } \geq 359 \mathrm{mg} / \mathrm{kg} \text { bw/day } \\
\text { ○ decreased body weight gain } \\
\text { - } 720 \mathrm{mg} / \mathrm{kg} \text { bw/day } \\
\text { ○ decreased body weight } \\
\text { ○ degeneration of the germinal epithelium } \\
\text { ○ focal atrophy of the seminiferous tubules } \\
\text { - } \geq 1540 \mathrm{mg} / \mathrm{kg} \text { bw/day } \\
\text { ○ decreased relative and absolute testicular, cauda epididymal } \\
\text { and left epididymal weight } \\
\text { O decreased serum testosterone level } \\
\text { ○ decreased zinc concentration in the testes } \\
\text { O decreased sperm count, motility and number of spermatid heads } \\
\text { per testis and per gram testis } \\
\text { ○ atrophy of Sertoli cells with vacuolated cytoplasm } \\
\text { - } 2964 \mathrm{mg} / \mathrm{kg} \text { bw/day } \\
\text { ○ degeneration of the germinal epithelium in all seminiferous } \\
\text { tubules with no spermatogenesis } \\
\text { - NOAEL } 359 \mathrm{mg} / \mathrm{kg} \text { bw/day }\end{array}$ & 23 \\
\hline \multicolumn{3}{|l|}{$\begin{array}{l}\text { Mice } \\
\text { short-term exposure }\end{array}$} \\
\hline $\begin{array}{l}\text { C57BL/6J mice (males, number } \\
\text { of animals - no data, } 4 \text { days old); } \\
\text { DBP was given orally in corn oil; } \\
\text { dose range: } 1-500 \mathrm{mg} / \mathrm{kg} \text { bw/day } \\
\text { for } 10 \text { days }\end{array}$ & $\begin{aligned} \text { - } & \geq 1 \mathrm{mg} / \mathrm{kg} \text { bw/day } \\
& \circ \text { decreased testicular weight } \\
& \circ \text { delayed spermatogenesis } \\
& \circ \text { reduced Sertoli cell proliferation } \\
& \circ \text { reduced anogenital distance } \\
- & \geq 10 \mathrm{mg} / \mathrm{kg} \mathrm{bw} / \text { day } \\
& \circ \mathrm{impaired} \mathrm{Sertoli} \mathrm{cell} \mathrm{maturation} \\
- & 500 \mathrm{mg} / \mathrm{kg} \text { bw/day } \\
& \circ \text { decreased serum testosterone and testicular } \\
& \circ \text { androgen activity } \\
\text { - } & \text { LOAEL } \geq 1 \mathrm{mg} / \mathrm{kg} \mathrm{bw} / \text { day }\end{aligned}$ & 24 \\
\hline \multicolumn{3}{|l|}{ sub-chronic exposure } \\
\hline $\begin{array}{l}\text { B6C3F1 mice (10 males/group, } \\
\text { 29-30 weeks old); DBP was given } \\
\text { via food: } 0 \%, 0.125 \%, 0.25 \%, 0.5 \% \text {, } \\
1.0 \%, 2.0 \% \text { (average: } 0,163,353,812 \text {, } \\
1601,3689 \mathrm{mg} / \mathrm{kg} \text { bw) for } 13 \text { weeks }\end{array}$ & $\begin{aligned} \text { - } & \geq 163 \mathrm{mg} / \mathrm{kg} \mathrm{bw} / \mathrm{day} \\
& \circ \text { increased serum testosterone level } \\
\text { - } & \geq 812 \mathrm{mg} / \mathrm{kg} \text { bw/day } \\
& \circ \text { increased zinc concentration in the testes } \\
- & 3689 \mathrm{mg} / \mathrm{kg} \text { bw/day } \\
& \circ \text { reduced left epididymal weight } \\
& \circ \text { reduced body weight } \\
& \circ \text { higher number of spermatid heads per gram in the testes } \\
\text { - } & \text { NOAEL } 353 \mathrm{mg} / \mathrm{kg} \mathrm{bw} / \text { day }\end{aligned}$ & 23 \\
\hline
\end{tabular}


Table 1. The effects of dibutyl phthalate (DBP) on male animal reproduction - short-term and sub-chronic exposure - cont.

\begin{tabular}{|c|c|c|}
\hline Study data & Results & Reference \\
\hline \multicolumn{3}{|l|}{ Rabbits } \\
\hline \multicolumn{3}{|l|}{ sub-chronic exposure } \\
\hline $\begin{array}{l}\text { adult male rabbits ( } 5 \text { males/group, } \\
\text { 6- } 6.5 \text { months old); DBP was given } \\
\text { orally } 3 \text { times a week for } 7 \text { weeks; } \\
\text { dose: } 520 \mathrm{mg} / \mathrm{kg} \text { bw/day }\end{array}$ & $\begin{array}{l}\text { - } 520 \mathrm{mg} / \mathrm{kg} \text { bw/day } \\
\circ \text { decreased prostate and testicular weight } \\
\circ \text { reduced intratesticular and serum testosterone levels } \\
\circ \text { decreased sperm count } \\
\circ \text { no changes in the total superoxide dismutase, glutathione peroxi- } \\
\text { dase activities, FSH and LH serum concentration }\end{array}$ & 25 \\
\hline $\begin{array}{l}\text { Dutch-Belted rabbits ( } 6 \text { males/group, } \\
25 \text { weeks old); DBP was given orally } \\
\text { via gavage in a mixture of deionized } \\
\text { water with corn syrup; doses: } \\
0,400 \mathrm{mg} / \mathrm{kg} \text { bw/day at PNW } 4-12 \\
\text { ( } 8 \text { weeks) }\end{array}$ & $\begin{array}{l}\text { - } 400 \mathrm{mg} / \mathrm{kg} \mathrm{bw} / \mathrm{day} \\
\text { ○ reduced serum testosterone level } \\
\text { ○ increased abnormal sperm } \\
\text { ○ altered response to gonadotropin release } \\
\text { ○ reduced accessory sex glands weight } \\
\text { - } \text { LOAEL } 400 \mathrm{mg} / \mathrm{kg} \mathrm{bw} / \text { day }\end{array}$ & 26 \\
\hline \multicolumn{2}{|l|}{ Monkeys } & short-term exposure \\
\hline $\begin{array}{l}\text { marmoset monkeys ( } 4 \text { males/group, } \\
\text { 4-6 days old); DBP was given } \\
\text { orally via gavage in corn oil; } \\
\text { doses: } 0,500 \mathrm{mg} / \mathrm{kg} \text { bw/day } \\
\text { for } 14 \text { consecutive days; the animals } \\
\text { were killed } 4 \mathrm{~h} \text { after the last treatment }\end{array}$ & $\begin{array}{l}\text { - } 500 \mathrm{mg} / \mathrm{kg} \mathrm{bw} / \mathrm{day} \\
\quad \mathrm{increased} \text { Leydig cell volume in the testes }\end{array}$ & 27 \\
\hline
\end{tabular}

DBP - dibutyl phthalate; FSH - follicle stimulating hormone; LH - luteinizing hormone; LOAEL - lowest observed adverse effect level;

NOAEL - no-observed adverse effect level; PNW - postnatal week.

When given in subcutaneous injections for 9 consecutive days at a dose of $1000 \mathrm{mg} / \mathrm{kg}$ bw, DBP resulted in the presence of multinuclear germ cells and hyperplasia of Leydig cells in the seminiferous tubules [13]. In the monkeys exposed orally via gavage to $500 \mathrm{mg} \mathrm{DBP} / \mathrm{kg}$ bw/day, steroidogenesis suppression by fetal type Leydig cells was observed [27]. The same process occurred in rodents but with a higher dose $-1000 \mathrm{mg} / \mathrm{kg}$ bw/day given via subcutaneous injections [13,27].

When given via food at a dose of $1540 \mathrm{mg} / \mathrm{kg}$ bw/day for 13 weeks, DBP resulted in the atrophy of Sertoli cells with vacuolated cytoplasm, decreased zinc concentrations in the testes, a decreased number of spermatid heads per testis and per gram testis, decreased testicular weight, and a lower serum testosterone level [23]. In another study in which F344 rats received DBP (1535 mg/kg bw/day) via food for 28 days, the animals demonstrated seminiferous degeneration, diminished spermatogenesis with morphological changes in sperm, and vacuolization of spermatogonia [22].

The rats treated with DBP orally at a dose of $2000 \mathrm{mg} / \mathrm{kg}$ bw/day (via gavage) for 9 days had most of the previously described adverse effects (Table 1), with an additional effect being an increased activity of the marker enzymes of oxidative stress [14]. Exposing rats to $2964 \mathrm{mg} / \mathrm{kg}$ bw/day of DBP, which was given via food for 13 weeks, only resulted in degeneration of the germinal epithelium in all seminiferous tubules [23].

The result of treating mice with the highest dose of DBP (3689 mg/kg bw/day), which was given via food, appears 
interesting as it caused an increased number of spermatid heads per gram in the testis [23].

In conclusion, in the studies of DBP reprotoxicity in experimental animals, the most common effects of exposure were reduced fertility [14-26], atrophic changes in male gonads $[19,23]$, as well as a reduction in sperm parameters [14-16,18,21,23,25], and other genital defects [13,20$22,24,26,27]$. Laboratory animals were exposed orally (via gavage or food) and via subcutaneous injections. No literature data on the inhalation exposure were found.

Besides the dose, the most important difference, when comparing these data, is the exact exposure time and what comes through it - the cumulative dose in the animal body. Noteworthy is the fact that lower doses cause more adverse effects than the highest dose (3689 mg/kg bw/day) [23].

\section{Embryotoxicity and teratogenicity}

Data on the embryotoxic and teratogenic effects of exposure are presented in Table 2 (32 studies conducted on rats) [28-60]. Only rat studies assessed the embryotoxic and teratogenic effects of DBP. The table is divided by exposure time (females exposed at different stages of pregnancy: 22 studies, females exposed at different periods of pregnancy and lactation: 7 studies, and 2-generation groups: 3 studies).

In the pregnant rats treated with the lowest dose of DBP (1.5-3.0 mg/kg bw via food), from gestational day (GD) 15 to postnatal day (PND) 21, changes in the mammary glands in both sexes, with degeneration and atrophy of the mammary gland follicles, were observed along with an increased relative weight of the pituitary in males and reduced spermatocyte development in the F1 generation [55].

A higher dose of DBP (10 mg/kg bw) given to pregnant rats from GD 14 until delivery had a negative impact not only on the dams (longer gestation, a reduced female body weight gain) but also on F1 males (a decreased anogenital distance and a reduction in the testosterone level in adult males) [37].
When the dose was increased to $15-30 \mathrm{mg} / \mathrm{kg}$ bw, a reduction in the follicle stimulating hormone was observed when DBP was given at GD 15-PND 21 [55].

Dibutyl phthalate given orally to pregnant rats at a dose of $50 \mathrm{mg} / \mathrm{kg}$ bw at GD 12-19 resulted in a reduction of the testicular testosterone level and some enzymes (Table 2) [34]. When the treatment with the same dose of DBP was elevated from GD 14 until delivery, a reduction in body weight, prostate and epididymis in F1 males was observed [37].

In a 2-generation study, F0 females exposed to $\geq 80 \mathrm{mg} / \mathrm{kg}$ bw of DBP via food before gestation resulted in a decrease in the live pup weight and the total number of live pups per litter. In turn, 1 in $20 \mathrm{~F} 1$ males, when given $\geq 52 \mathrm{mg} / \mathrm{kg}$ bw of DBP via food, had absent or not fully developed epididymis $[23,60]$.

Treating the dams with $100 \mathrm{mg} / \mathrm{kg}$ bw of DBP (via gavage) on GD 1, 7 and 14 resulted in a decreased sperm count, motility, viability with morphological changes in sperm, and a decreased steroidogenic enzyme activity level in F1 males [32]. When pregnant $\mathrm{CD}$ rats were treated orally with $100 \mathrm{mg} / \mathrm{kg}$ bw/day of DBP at GD 12-21, the following effects were observed: a delay in preputial separation in F1 males [44]; metaplasia of the prostate epithelial cells, an increase in androgen receptor expression, metalloproteinase-9 activity and the proliferation index [52]; a decrease in the testes size and weight, Leydig cell hyperplasia areas, degeneration of the seminiferous tubules and Sertoli cells, an increase in the luteinizing hormone level, a decrease in the testosterone level [43]; Leydig cell clusters, multinucleated germinative cells, and an increase in the intersticial component [53]; testicular Leydig cells [42]; an increase in the epithelial compartment of the prostate gland, an increase in the incidence of metaplasia, inflammation and endothelial prostate cancer [54]; and retained areolas or nipples in F1 males [45,46].

When given at a dose of $100 \mathrm{mg} / \mathrm{kg}$ bw/day to the dams at GD 12-19, DBP caused a reduction in testicular mRNA 
Table 2. Embryotoxic and teratogenic effects of dibutyl phthalate (DBP) in female rats - exposure at different stages of pregnancy, lactation and a 2-generation study

\begin{tabular}{|c|c|c|}
\hline Study data & Results & Reference \\
\hline \multicolumn{3}{|l|}{$\begin{array}{l}\text { Females exposed at different stages } \\
\text { of pregnancy }\end{array}$} \\
\hline $\begin{array}{l}\text { Spraque-Dawley rats (pregnant } \\
\text { females); DBP was given orally } \\
\text { at GD } 14 \text {; single dose: } 0,500,1000 \text {, } \\
1500 \text { or } 2000 \mathrm{mg} / \mathrm{kg} \text { bw; the dams } \\
\text { were killed at GD } 21\end{array}$ & $\begin{aligned} \text { - } & \geq 1000 \mathrm{mg} / \mathrm{kg} \mathrm{bw} \\
& \circ \text { increased incidence of skeletal malformations } \\
\text { - } & \geq 1500 \mathrm{mg} / \mathrm{kg} \mathrm{bw} \\
& \circ \text { statistically significantly decreased female body weight gain } \\
& \circ \text { statistically significantly decreased uterine weight } \\
& \circ \text { increased resorption frequency } \\
& \circ \text { reduced fetal body weight } \\
- & 2000 \mathrm{mg} / \mathrm{kg} \text { bw } \\
& \circ \text { reduced number of live fetuses }\end{aligned}$ & 28 \\
\hline $\begin{array}{l}\text { Wistar rats (pregnant females); } \\
\text { DBP was given via gastric intubation } \\
\text { on } 1 \text { day, between GD } 6 \text { and } 16 ; \\
\text { single dose: } 1500 \mathrm{mg} \text { DBP } / \mathrm{kg} \text { bw; } \\
\text { at GD } 20 \text {, the females were killed } \\
\text { to assess malformations } \\
\text { in the fetuses }\end{array}$ & $\begin{array}{l}\text { - decreased female body weight gain } \\
\text { - fetuses with skeletal malformations and/or internal/external } \\
\text { malformations were observed only when DBP was given at GD 8,9 or } 15 \\
\text { - after day 8, only deformations of the cervical vertebrae were noted } \\
\text { - in the fetuses treated with DBP on day 9, deformations of the cervical } \\
\text { and thoracic vertebrae, ribs, and dilatation of the renal pelvis were } \\
\text { observed } \\
\text { - DBP given at GD } 15 \text { resulted in cleft palate and sternebrae fusion }\end{array}$ & 29 \\
\hline $\begin{array}{l}\text { Sprague Dawley rats } \\
\text { ( } 55 \text { pregnant females); DBP was } \\
\text { given orally via gavage at GD } 17 \\
\text { ( } 20 \text { females) or at GD } 18 \\
\text { ( } 35 \text { females); dose: } 500 \mathrm{mg} / \mathrm{kg} \mathrm{bw} \text {; } \\
\text { the animals were killed after } 2,4 \text {, } \\
6,24 \mathrm{~h} \text {, or given the second dose } \\
\text { after } 24 \text { h and then killed } 48 \mathrm{~h} \\
\text { after the first dose }\end{array}$ & $\begin{array}{l}\text { - } 500 \mathrm{mg} / \mathrm{kg} \text { bw } \\
\circ \text { multinucleated germ cells were observed in the testes of male fetuses } \\
\text { 4-6 h after exposure at GD } 18 \text { (no changes were observed at GD 17) } \\
\text { elevated seminiferous cord diameter in the testes during the fetal period } \\
\text { and cell death }\end{array}$ & 30 \\
\hline $\begin{array}{l}\text { Wistar rats (pregnant females); } \\
\text { DBP was given orally via gavage } \\
\text { at GD 7-9, } 10-12 \text { or } 13-15 \text {; } \\
\text { doses: } 750,1000 \text { or } 1500 \mathrm{mg} / \mathrm{kg} \text { bw }\end{array}$ & $\begin{array}{l}\text { - } \geq 750 \mathrm{mg} / \mathrm{kg} \mathrm{bw} \\
\text { ○ significantly increased skeletal malformations (deformities } \\
\text { of the vertebratal column in the thoracic and cervical regions } \\
\text { of the ribs) - in dams exposed at GD 7-9 } \\
\text { O significantly increased incidence of skeletal malformations, } \\
\text { including those visible to the outside, e.g., cleft palate and fusion } \\
\text { of the sternebrae - in the dams exposed at GD } 13-15 \text { significantly in- } \\
\text { creased postimplantation loss } \\
\text { - } \geq 1500 \mathrm{mg} / \mathrm{kg} \text { bw } \\
\text { - } 100 \% \text { postimplantation loss (in all females regardless } \\
\text { of the GD at which they were exposed) } \\
\text { - LOAEL } 750 \mathrm{mg} / \mathrm{kg} \text { bw/day (teratogenicity) }\end{array}$ & 31 \\
\hline
\end{tabular}


Table 2. Embryotoxic and teratogenic effects of dibutyl phthalate (DBP) in female rats - exposure at different stages of pregnancy, lactation and a 2-generation study - cont.

\begin{tabular}{|c|c|c|}
\hline Study data & Results & Reference \\
\hline \multicolumn{3}{|l|}{$\begin{array}{l}\text { Females exposed at different stages } \\
\text { of pregnancy - cont. }\end{array}$} \\
\hline $\begin{array}{l}\text { Wistar rats (pregnant females); } \\
\text { DBP was given via gavage in } \\
\text { corn oil at GD } 1,7 \text { and } 14 ; \\
\text { doses: } 0,100,500 \mathrm{mg} / \mathrm{kg} \text { bw/day; } \\
\text { at PND 100, the } \mathrm{F} 1 \text { male rats were } \\
\text { used for mating with normal females }\end{array}$ & $\begin{array}{l}\text { - F1 generation } \\
\begin{aligned} 0 & \geq 100 \mathrm{mg} / \mathrm{kg} \text { bw } \\
& \square \text { decreased fertility (decreased sperm count, motility, viability) } \\
& \square \text { morphological abnormalities in sperm (hypoosmotic swelling } \\
& \quad \text { tail coiled sperms) } \\
& \square \text { decreased serum testosterone level } \\
& \square \text { decreased steroidogenic enzyme activity level }\end{aligned}\end{array}$ & 32 \\
\hline $\begin{array}{l}\text { Sprague-Dawley rats (groups } \\
\text { of } 3-4 \text { pregnant females); } \\
\text { DBP was given orally } \\
\text { via gavage at GD 12-21; doses: } \\
0,500 \mathrm{mg} / \mathrm{kg} \text { bw/day; examination } \\
\text { of the male reproductive tract } \\
\text { at GD } 16-21 \text {, and at PND } 3,7,16 \text {, } \\
21,45 \text { and } 70\end{array}$ & $\begin{array}{l}500 \mathrm{mg} / \mathrm{kg} \mathrm{bw} / \mathrm{day} \\
\square \text { multinucleated gonocytes } \\
\square \text { increased number of gonocytes and aggregates of Leydig cells } \\
\text { in the testes during the fetal period } \\
\square \text { decreased number of spermatocytes (at PND } 16 \text { and 21) connected } \\
\text { with mild to severe degeneration of the seminiferous epithelium } \\
\text { (at PND 70) } \\
\square \text { ipsilaterally malformed epididymides leading to obstruction } \\
\text { of testicular fluid flow }\end{array}$ & 33 \\
\hline $\begin{array}{l}\text { Sprague-Dawley rats (groups } \\
\text { of } 11 \text { pregnant females); } \\
\text { DBP was given via gavage in corn oil } \\
\text { at GD } 12-19 \text {; doses: } 0,0.1,1,10,30 \text {, } \\
50,100,500 \mathrm{mg} / \mathrm{kg} \mathrm{bw} / \text { day }\end{array}$ & 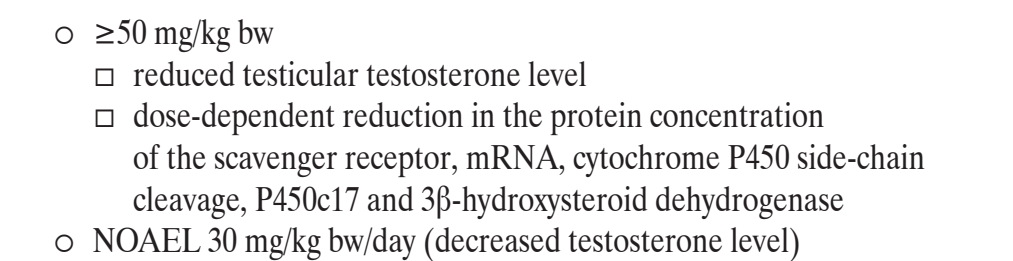 & 34 \\
\hline $\begin{array}{l}\text { pregnant CD rats; DBP was given } \\
\text { via food at GD } 12-19 ; \text { doses: } 0,100 \text {, } \\
500 \mathrm{mg} / \mathrm{kg} / \text { day; the animals were } \\
\text { killed } 4 \mathrm{~h} \text { or } 24 \mathrm{~h} \text { after treatment. }\end{array}$ & $\begin{array}{l}\square>100 \mathrm{mg} / \mathrm{kg} / \mathrm{day} \\
\square \text { reduction in testicular mRNA concentration, cytochrome P450 family } \\
\text { and P450 family 17, steroidogenic acute regulatory protein } \\
\square \text { reduced testicular testosterone level } \\
\square \text { significant reduction in the male offspring anogenital distance } \\
\square \text { Leydig cell aggregates, multinucleated gonocytes, increased cord } \\
\text { diameters }\end{array}$ & 35 \\
\hline $\begin{array}{l}\text { Wistar rats (pregnant females); } \\
\text { DBP was given orally via gavage } \\
\text { in corn oil at GD } 13.5-20.5 / 21.5 \text {; } \\
\text { doses: } 0,4,20,100 \text {, } \\
500 \mathrm{mg} / \mathrm{kg} \text { bw/day }\end{array}$ & 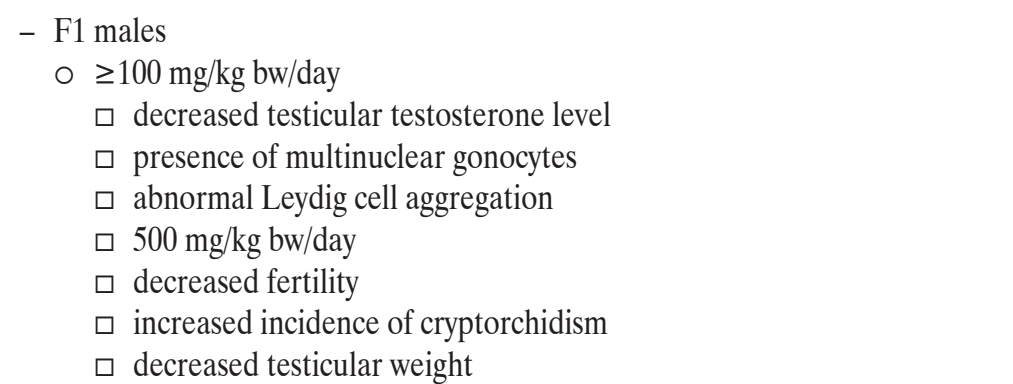 & 36 \\
\hline
\end{tabular}


Table 2. Embryotoxic and teratogenic effects of dibutyl phthalate (DBP) in female rats - exposure at different stages of pregnancy, lactation and a 2-generation study - cont.

\begin{tabular}{|c|c|c|}
\hline Study data & Results & Reference \\
\hline \multicolumn{3}{|l|}{$\begin{array}{l}\text { Females exposed at different stages } \\
\text { of pregnancy - cont. }\end{array}$} \\
\hline $\begin{array}{l}\text { rats (pregnant females); } \\
\text { DBP was given orally via gavage } \\
\text { from GD } 14 \text { until delivery; } \\
\text { doses: } 2,10 \text { and } 50 \mathrm{mg} / \mathrm{kg} \text { bw }\end{array}$ & $\begin{aligned}- & \geq 10 \mathrm{mg} / \mathrm{kg} \text { bw } \\
& \text { significant reduction in female body weight at GD } 21 \\
& \circ \text { elevated length of gestation } \\
& \text { decreased anogenital distance in F1 males } \\
& \text { reduced testosterone level in adult F1 males } \\
- & 50 \mathrm{mg} / \mathrm{kg} \mathrm{bw} \\
& \text { reduced body weight in F1 males } \\
& \text { slightly reduced epididymis and prostate weight in F1 males } \\
& \text { slightly decreased daily sperm production and testicular } \\
& \text { spermatid count }\end{aligned}$ & 37 \\
\hline $\begin{array}{l}\text { rats (pregnant females); } \\
\text { DBP was given orally via gastric } \\
\text { intubation; doses: } 0,500,630,750 \\
\text { or } 1000 \mathrm{mg} / \mathrm{kg} \text { bw at GD } 7-15\end{array}$ & $\begin{array}{l}\text { - } \geq 500 \mathrm{mg} / \mathrm{kg} \text { bw/day } \\
\text { ○ significantly decreased maternal body weight gain } \\
\text { (a statistically significant change from a dose of } 630 \mathrm{mg} / \mathrm{kg} \mathrm{bw} \text { ) } \\
\circ \text { resorptions of the implanted embryos } \\
\circ \text { decreased fetal weight (a statistically significant change from } \\
\text { a dose of } 750 \mathrm{mg} / \mathrm{kg} \mathrm{bw)} \\
-\geq 630 \mathrm{mg} / \mathrm{kg} \mathrm{bw} / \mathrm{day} \\
\circ \text { increased number of dead fetuses } \\
\text { ○ increased incidence of malformations (mainly cleft palate; } \\
\text { a statistically significant change from a dose of } 750 \mathrm{mg} / \mathrm{kg} \mathrm{bw} \\
\text { only in young males) } \\
\circ \text { decreased fetal weight } \\
\circ \text { increased incidence of postimplantation loss } \\
-1000 \mathrm{mg} / \mathrm{kg} \text { bw/day } \\
\circ \text { complete resorption of the implanted embryos } \\
\circ 2 \text { maternal deaths }\end{array}$ & 38 \\
\hline $\begin{array}{l}\text { Wistar rats (pregnant females); } \\
\text { DBP was given orally via gavage; } \\
\text { doses: } 0,500 \mathrm{mg} / \mathrm{kg} \text { bw/day } \\
\text { at GD } 13-21\end{array}$ & $\begin{array}{l}\text { - } 500 \mathrm{mg} / \mathrm{kg} \text { bw/day } \\
\text { ○ unilateral cryptorchidism, infertility, hypospadias, testis abnormalities in } \\
\text { F1 males (similar to those seen in people with TDS) } \\
\circ 60 \% \text { cryptorchidism, hypospadias, testicular abnormalities } \\
\text { (similar to those seen in people with TDS) } \\
\text { O immature Sertoli cells }\end{array}$ & 39 \\
\hline $\begin{array}{l}\text { Sprague-Dawley rats (pregnant } \\
\text { females); DBP was given orally } \\
\text { via gavage in corn oil; doses: } 0,250 \\
500,700 \mathrm{mg} / \mathrm{kg} \text { bw/day at GD } 10-19 \text {; } \\
\text { the pups were killed at PND } 31 \text { or } 42\end{array}$ & $\begin{array}{l}-\geq 250 \mathrm{mg} / \mathrm{kg} \text { bw } \\
\text { ○ decreased testicular, seminal vesicles, epididymides and Cowper's gland } \\
\text { weight } \\
\text { ○ significantly delayed testis descent } \\
\text { ○ decreased serum testosterone level }\end{array}$ & 40 \\
\hline $\begin{array}{l}\text { Sprague-Dawley rats (pregnant } \\
\text { females); DBP was given } \\
\text { orally via gavage; doses: } \\
0,500 \mathrm{mg} / \mathrm{kg} \text { bw/day at GD } 12-20\end{array}$ & $\begin{array}{l}-500 \mathrm{mg} / \mathrm{kg} \text { bw/day } \\
\circ \text { testicular atrophy in males (decreased sperm production, } \\
\text { degeneration of seminiferous epithelium) } \\
\circ \text { malformations of the male reproductive system } \\
\circ \text { Leydig cell aggregation } \\
\circ \text { reduced testosterone level } \\
\circ \text { multinucleated gonocytes }\end{array}$ & 41 \\
\hline
\end{tabular}


Table 2. Embryotoxic and teratogenic effects of dibutyl phthalate (DBP) in female rats - exposure at different stages of pregnancy, lactation and a 2-generation study - cont.

\begin{tabular}{|c|c|c|}
\hline Study data & Results & Reference \\
\hline \multicolumn{3}{|l|}{$\begin{array}{l}\text { Females exposed at different stages } \\
\text { of pregnancy - cont. }\end{array}$} \\
\hline $\begin{array}{l}\text { Sprague Dawley rats ( } 20 \text { pregnant } \\
\text { females); DBP was given orally } \\
\text { at GD 12-21; doses: } 10,30,50 \\
\text { or } 100 \mathrm{mg} / \mathrm{kg} \text { bw/day }\end{array}$ & $\begin{array}{l}\text { - } 100 \mathrm{mg} / \mathrm{kg} \mathrm{bw} / \mathrm{day} \\
\circ \text { reduced testicular weight } \\
\circ \text { testicular Leydig cells } \\
\circ \text { decreased serum testosterone level } \\
\text { ○ reduced LH level at PNW 5-7 and its increase } \\
\text { at PNW 9-17 (compared to the controls) }\end{array}$ & 42 \\
\hline $\begin{array}{l}\text { Sprague Dawley rats ( } 4 \text { pregnant } \\
\text { females); DBP was given orally } \\
\text { in corn oil at GD 12-21; dose: } \\
100 \mathrm{mg} / \mathrm{kg} \text { bw/day; the young males } \\
\text { were killed at PNW } 20\end{array}$ & $\begin{array}{l}\text { - } 100 \mathrm{mg} / \mathrm{kg} \text { bw/day } \\
\circ \text { decreased testes size and testicular weight at PNW } 20 \\
\circ \text { Leydig cell hyperplasia areas } \\
\circ \text { degeneration of the seminiferous tubules and Sertoli cells } \\
\text { (disturbed spermatogenesis in several seminiferous tubules) } \\
\circ \text { increased LH level } \\
\circ \text { decreased testosterone level }\end{array}$ & 43 \\
\hline $\begin{array}{l}\text { CD rats (pregnant females); } \\
\text { DBP was given orally via gavage } \\
\text { at GD 12-21; doses: } 0,100,250 \\
\text { or } 500 \mathrm{mg} / \mathrm{kg} \text { bw/day }\end{array}$ & $\begin{array}{l}\text { - } \geq 100 \mathrm{mg} / \mathrm{kg} \text { bw } \\
\circ \text { delayed preputial separation } \\
\text { - } \geq 250 \mathrm{mg} / \mathrm{kg} \text { bw } \\
\circ \text { malformations of the reproductive organs in F1 males } \\
\text { (decreased anogenital distance and retained thoracic nipples) } \\
\text { - } 500 \mathrm{mg} / \mathrm{kg} \text { bw } \\
\circ \text { in male offspring: hypospadias, epididymal agenesis, prostate } \\
\text { and vas deferens, cryptorchidism, degeneration of the seminiferous } \\
\text { epithelium, intersticial cell hyperplasia of the testis } \\
\text { intersticial cell adenoma (in 2 F1 males) } \\
\circ \text { reduced body weight of } 1 \text { female after GD } 18 \text { and birth of dead } \\
\text { or exhausted pups } \\
\text { - in F1 females, no abnormalities related to the development } \\
\text { of reproductive organs and kidneys were observed }\end{array}$ & 44 \\
\hline $\begin{array}{l}\text { CD rats (pregnant females); } \\
\text { DBP was given orally via gavage } \\
\text { at GD } 12-21 \text {; doses: } 0,0.5,5,50,100 \text {, } \\
500 \mathrm{mg} / \mathrm{kg} / \text { day }\end{array}$ & $\begin{array}{l}\text { - } 100 \mathrm{mg} / \mathrm{kg} / \text { day } \\
\text { ○ retained areolas or nipples in the male offspring } \\
\text { - } 500 \mathrm{mg} / \mathrm{kg} / \text { day } \\
\text { ○ decreased anogenital distance, hypospadias } \\
\text { ○ partially developed or absent epididymis, seminal vesicles, } \\
\text { ventral prostate and vas deferens } \\
\text { O decreased weight of the epididymis, testes, ventral and dorsolateral } \\
\text { prostates, levator anti-bulbocavernosus and seminal vesicles } \\
\text { at PND } 110 \\
\text { o prevalent seminiferous tubule degeneration, intersticial cell adenoma, } \\
\text { focal intersticial cell hyperplasia } \\
\text { - NOAEL } 50 \mathrm{mg} / \mathrm{kg} \text { bw/day } \\
\text { - LOAEL } 100 \mathrm{mg} / \mathrm{kg} \text { bw/day }\end{array}$ & 45,46 \\
\hline
\end{tabular}


Table 2. Embryotoxic and teratogenic effects of dibutyl phthalate (DBP) in female rats - exposure at different stages of pregnancy, lactation and a 2-generation study - cont.

\begin{tabular}{|c|c|c|}
\hline Study data & Results & Reference \\
\hline \multicolumn{3}{|l|}{$\begin{array}{l}\text { Females exposed at different stages } \\
\text { of pregnancy - cont. }\end{array}$} \\
\hline $\begin{array}{l}\text { Sprague-Dawley rats (pregnant } \\
\text { females); DBP was given } \\
\text { orally via gavage at GD } 12-21 \text {; } \\
\text { dose: } 0,500 \mathrm{mg} / \mathrm{kg} \text { bw/day }\end{array}$ & $\begin{array}{l}\text { - } 500 \mathrm{mg} / \mathrm{kg} \text { bw/day } \\
\circ \text { decreased androstenedione and testicular testosterone levels } \\
\circ \text { reduced steroidogenesis }\end{array}$ & 47 \\
\hline $\begin{array}{l}\text { Sprague-Dawley rats (pregnant } \\
\text { females - groups of } 3-4 \text { dams); } \\
\text { DBP was given via gavage } \\
\text { in corn oil at GD 12-21; } \\
\text { doses: } 0,500 \mathrm{mg} / \mathrm{kg} \text { bw/day, } \\
\text { testes examination in the offspring }\end{array}$ & $\begin{array}{l}-500 \mathrm{mg} / \mathrm{kg} \text { bw/day } \\
\circ \text { enlarged seminiferous cords in fetuses } \\
\circ \text { Leydig cell hyperplasia } \\
\circ \text { atrophic changes in the testes } \\
\circ \text { decreased serum testicular testosterone level } \\
\circ \text { decreased sperm production } \\
\circ \text { reproductive tract malformations } \\
\bigcirc \text { adenomas }\end{array}$ & 48 \\
\hline $\begin{array}{l}\text { Sprague-Dawley rats (pregnant } \\
\text { females - } 4 \text { dams/group); } \\
\text { DBP was given orally via gavage } \\
\text { at GD } 8-18 \text {; doses: } 0,33,50,100 \text {, } \\
300,600 \mathrm{mg} / \mathrm{kg} \text { bw/day }\end{array}$ & $\begin{array}{l}\text { - } \geq 300 \mathrm{mg} / \mathrm{kg} \text { bw } \\
\text { ○ reduced testosterone production } \\
\text { - NOAEL } 100 \mathrm{mg} / \mathrm{kg} \mathrm{bw} / \text { day }\end{array}$ & 49 \\
\hline $\begin{array}{l}\text { Wistar rats (pregnant females); } \\
\text { DBP was given via food } \\
\text { at GD } 11-21 \text {; doses: } \sim 0,331,555 \\
\text { or } 661 \mathrm{mg} / \mathrm{kg} \text { bw }\end{array}$ & $\begin{array}{l}\text { - } \geq 555 \mathrm{mg} / \mathrm{kg} \text { bw } \\
\text { O significantly reduced feed intake and body weight gain } \\
\text { ○ increased incidence of cryptorchidism } \\
\text { ○ decreased anogenital distance of male fetuses } \\
\text { - } 661 \mathrm{mg} / \mathrm{kg} \text { bw } \\
\text { ○ decreased weight of female and male fetuses } \\
\text { ○ increased incidence of fetal fusion of the sternebrae and cleft palate } \\
\text { - the number of live fetuses, the incidence of postimplantation loss, dead } \\
\text { fetuses or resorptions did not differ in comparison to the controls } \\
\text { - NOAEL } 331 \mathrm{mg} / \mathrm{kg} \text { bw/day }\end{array}$ & 50 \\
\hline \multicolumn{3}{|l|}{$\begin{array}{l}\text { Females exposed at different periods } \\
\text { of pregnancy and lactation }\end{array}$} \\
\hline $\begin{array}{l}\text { Sprague-Dawley rats ( } 9 \text { pregnant } \\
\text { females); DBP was given } \\
\text { orally at GD 14.5-PND 6; } \\
\text { dose: } 500 \mathrm{mg} / \mathrm{kg} \text { bw/day }\end{array}$ & $\begin{array}{l}\text { - } 500 \mathrm{mg} / \mathrm{kg} \text { bw/day } \\
\text { ○ gonadal dysgenesis (unilateral abdominal cryptorchidism and unilateral } \\
\text { anorchism at PND 24, unilateral testicular dysgenesis at PND 90) } \\
\text { ○ slightly reduced anogenital distance at PND } 24 \\
\text { ○ Leydig cell proliferation }\end{array}$ & 51 \\
\hline $\begin{array}{l}\text { rats ( } 10 \text { pregnant females); } \\
\text { DBP was given orally via gavage } \\
\text { at GD } 12-P N D 21 ; \\
\text { dose: } 100 \mathrm{mg} / \mathrm{kg} \text { bw/day; } \\
\text { the pups were killed at PND } 90\end{array}$ & $\begin{aligned} &- 100 \mathrm{mg} / \mathrm{kg} \text { bw/day } \\
& \circ \text { metaplasia of the prostate epithelial cells } \\
& \circ \text { increased androgen receptor expression, metalloproteinase- } 9 \text { activity and } \\
& \text { proliferation index } \\
& \circ \text { no change in the serum and testicular testosterone levels } \\
& \circ \text { no change in prostate weight }\end{aligned}$ & 52 \\
\hline
\end{tabular}


Table 2. Embryotoxic and teratogenic effects of dibutyl phthalate (DBP) in female rats - exposure at different stages of pregnancy, lactation and a 2-generation study - cont.

\begin{tabular}{|c|c|c|}
\hline Study data & Results & Reference \\
\hline \multicolumn{3}{|l|}{$\begin{array}{l}\text { Females exposed at different periods } \\
\text { of pregnancy and lactation - cont. }\end{array}$} \\
\hline $\begin{array}{l}\text { Wistar rats (10 pregnant } \\
\text { females); DBP was given orally } \\
\text { via gavage at GD 12-PND 21; } \\
\text { dose: } 100 \mathrm{mg} / \mathrm{kg} \text { bw/day; } 5 \text { dams } \\
\text { were killed at GD 20; } 5 \text { young males } \\
\text { were killed at PND } 90\end{array}$ & $\begin{array}{l}\text { - } 100 \mathrm{mg} / \mathrm{kg} \mathrm{bw} / \mathrm{day} \\
\text { ○ Leydig cell clusters } \\
\circ \text { presence of multinucleated germinative cells } \\
\circ \text { increased intersticial component } \\
\circ \text { decreased anogenital distance (statistically insignificant) }\end{array}$ & 53 \\
\hline $\begin{array}{l}\text { Wistar rats (pregnant females); } \\
\text { DBP was given orally via gavage } \\
\text { at GD 15-PND 21; doses: } 100 \text {, } \\
500 \mathrm{mg} / \mathrm{kg} \text { of DBP; the pups were } \\
\text { killed at PND } 220\end{array}$ & $\begin{aligned}- & \geq 100 \mathrm{mg} / \mathrm{kg} \\
& \circ \text { decreased anogenital distance in newborn males } \\
& \circ \text { increased epithelial compartment of the prostate gland } \\
& \circ \text { increased incidence of metaplasia and inflammation } \\
& \circ \text { increased incidence of endothelial prostate cancer in males }\end{aligned}$ & 54 \\
\hline $\begin{array}{l}\text { rats (females); DBP was given } \\
\text { via food; doses: } 0,20,200,2000 \\
\text { and } 10000 \mathrm{ppm}(0,1.5-3.0,15-30 \text {, } \\
150-3000,750 \mathrm{mg} / \mathrm{kg} \text { bw } \\
\text { at GD 15-PND 21) }\end{array}$ & 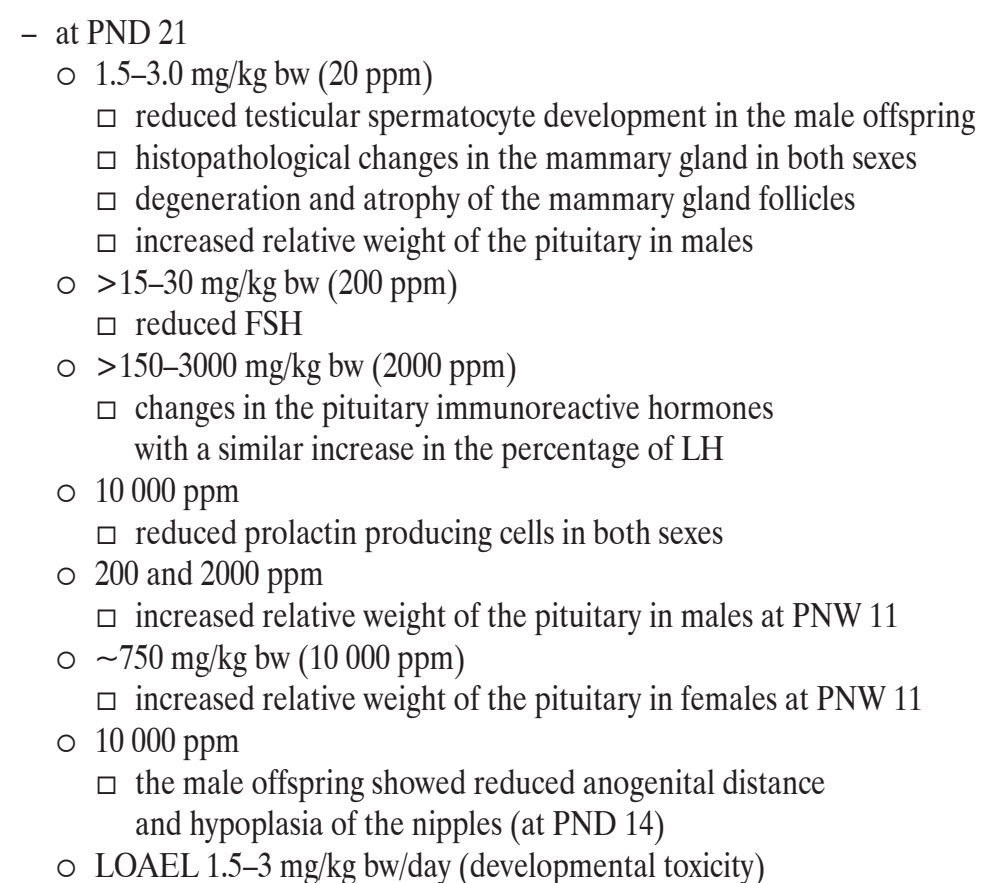 & 55 \\
\hline
\end{tabular}


Table 2. Embryotoxic and teratogenic effects of dibutyl phthalate (DBP) in female rats - exposure at different stages of pregnancy, lactation and a 2-generation study - cont.

\begin{tabular}{|c|c|c|}
\hline Study data & Results & Reference \\
\hline \multicolumn{3}{|l|}{$\begin{array}{l}\text { Females exposed at different periods } \\
\text { of pregnancy and lactation - cont. }\end{array}$} \\
\hline $\begin{array}{l}\text { CD rats (pregnant females (groups } \\
\text { of } 10 \text { dams); DBP was given orally } \\
\text { via gavage from GD } 3 \text { through } \\
\text { lactation to PND 20; doses: } 0,250 \text {, } \\
500 \text { or } 750 \mathrm{mg} / \mathrm{kg} \text { bw; the dams were } \\
\text { killed after lactation (at PND 21) } \\
\text { and the offspring after reaching } \\
\text { puberty (on day } 100-105 \text { of their life) }\end{array}$ & $\begin{array}{l}\text { - } \geq 250 \mathrm{mg} / \mathrm{kg} \text { bw/day } \\
\circ \text { at all doses, the epididymis was underdeveloped or absent } \\
\text { at PND 100, and it was connected with germ cell loss and testicular atro- } \\
\text { phy; hypospadias; and absent or ectopic testes } \\
-\geq 500 \mathrm{mg} / \mathrm{kg} \text { bw/day } \\
\circ \text { reduced uterine weight } \\
\circ \text { reduced anogenital distance in F1 males at birth, as well as small testes, } \\
\text { seminal vesicles and the absence of the prostate gland } \\
\text { - } 750 \mathrm{mg} / \mathrm{kg} \text { bw/day } \\
\circ \text { maternal effects on pregnancy } \\
\circ \text { postimplantation loss } \\
\circ \text { decreased number of live pups per litter at birth } \\
\text { O reduced prostate weight and average kidney weight } \\
\text { - the effects of DBP on the reproductive system in F1 females were insignificant } \\
\text { - the dam's body weight and the amount of feed consumed remained unchanged }\end{array}$ & 1 \\
\hline $\begin{array}{l}\text { Sprague-Dawley rats (pregnant } \\
\text { females); DBP was given orally } \\
\text { via gavage at GD 1-PND 21; } \\
\text { doses: } 0,50,250,500 \mathrm{mg} / \mathrm{kg} \text { bw/day }\end{array}$ & 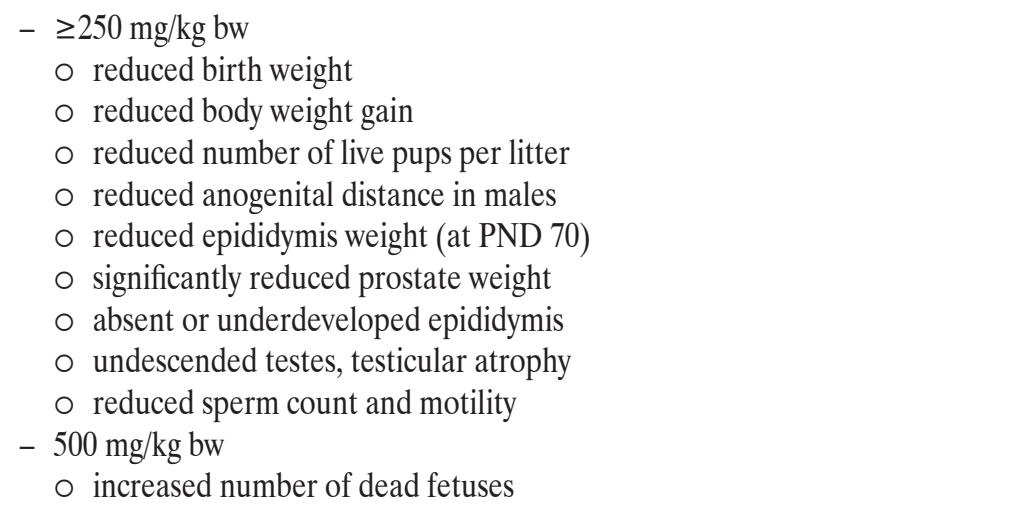 & 57 \\
\hline \multicolumn{3}{|l|}{ 2-generation study } \\
\hline $\begin{array}{l}\text { Long Evans rats (groups } \\
\text { of } 12-13 \text { pregnant females); } \\
\text { 2-generation study; exposure } \\
\text { from PND 20; DBP was given } \\
\text { via food; doses: } 0,250,500, \\
1000 \mathrm{mg} / \mathrm{kg} \text { bw } / \text { day }\end{array}$ & $\begin{aligned}- & \geq 500 \mathrm{mg} / \mathrm{kg} \text { bw } \\
& \circ \text { reduced fertility in } \mathrm{F} 1 \text { females } \\
& \circ \text { reduced number of litters in } \mathrm{F} 0 \text { females } \\
& \circ \text { reduced serum progesterone level in F0 females } \\
& \circ \text { increased estradiol production in F0 females } \\
& \circ \text { increased weight of the liver and kidneys } \\
\text { - } & \text { NOAEL } 250 \mathrm{mg} / \mathrm{kg} \mathrm{bw} / \text { day (F0 female fertility) }\end{aligned}$ & 58 \\
\hline $\begin{array}{l}\text { Sprague-Dawley rats ( } 17 \text { males } \\
\text { and } 17 \text { females/group); } 2 \text {-generation } \\
\text { study; DBP was given via food; } \\
\text { doses: } 1,4,10,30,100,1000, \\
10000 \mathrm{ppm} \text { (approx. } 0.1,0.4,1,3,10 \text {, } \\
\text { 100, } 1000 \mathrm{mg} / \mathrm{kg} \mathrm{bw} \text { ) }\end{array}$ & $\begin{aligned}- & \text { F1 males } \\
\circ & 1000 \mathrm{mg} / \mathrm{kg} \text { bw/day } \\
& \square \text { atrophy of vas deferens } \\
& \square \text { reduced anogenital distance } \\
& \square \text { delayed testis descent } \\
& \square \text { delayed preputial separation } \\
& \text { NOAEL } 1000 \mathrm{mg} / \mathrm{kg} \text { bw/day (systemic toxicity, effect on sperm) } \\
& \text { NOAEL } 100 \mathrm{mg} / \mathrm{kg} \mathrm{bw} / \text { day }\end{aligned}$ & 59 \\
\hline
\end{tabular}


Table 2. Embryotoxic and teratogenic effects of dibutyl phthalate (DBP) in female rats - exposure at different stages of pregnancy, lactation and a 2-generation study - cont.

\begin{tabular}{|c|c|c|}
\hline Study data & Results & Reference \\
\hline 2-generation study - cont. & & \\
\hline $\begin{array}{l}\text { Sprague-Dawley rats } \\
\text { (groups of } 20 \text { males } \\
\text { and } 20 \text { females); 2-generation } \\
\text { study (controls: } 40 \text { females } \\
\text { and } 40 \text { males); DBP was given } \\
\text { via food; doses: } 0,52,256 \\
\text { or } 509 \mathrm{mg} / \mathrm{kg} \text { bw/day (males) } \\
\text { and } 0,80,385 \text { or } 794 \mathrm{mg} / \mathrm{kg} \text { bw/day } \\
\text { (females); the F1 males and females } \\
\text { exposed to the highest dose } \\
\text { of DBP were involved in the study } \\
\text { on fertility, pregnancy and mating } \\
\text { to deliver F2 offspring }\end{array}$ & 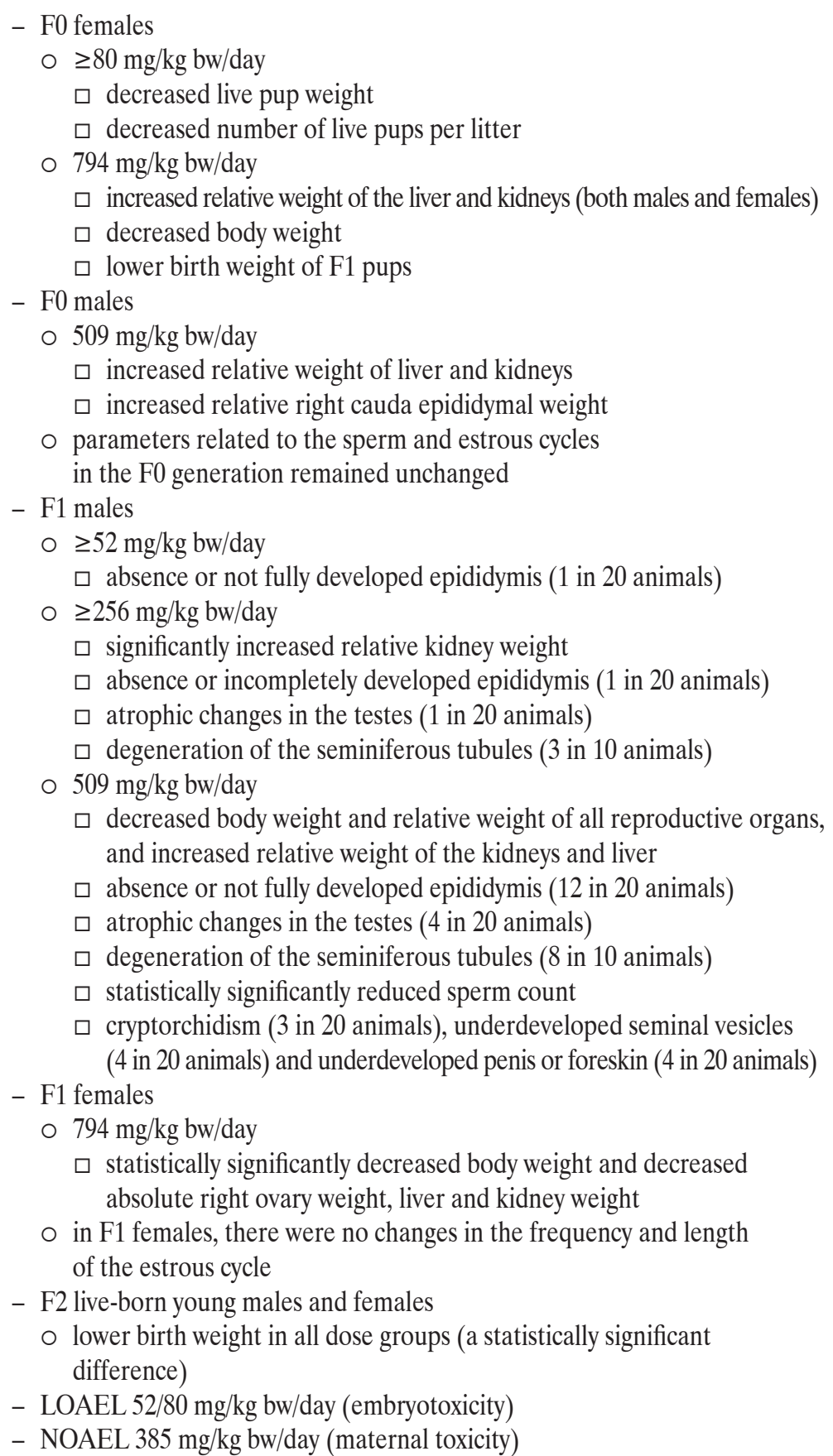 & 23,60 \\
\hline
\end{tabular}

GD - gestational day; PND - postnatal day; TDS - testicular dysgenesis syndrome.

Other abbreviations as in Table 1. 
concentration, cytochrome P450, and steroidogenic acute regulatory protein, along with an increased cord diameter [35]. When given at a dose of $100 \mathrm{mg} / \mathrm{kg}$ bw/day (via gavage) at GD 13.5-20.5/21.5, in F1 males besides the altered testosterone level (which was observed at lower doses - beginning from $10 \mathrm{mg} / \mathrm{kg}$ bw [34,37]), multinucleated gonocytes and abnormal Leydig cell aggregation were also noted [36], and when the exposure time was GD 1-PND 21, a reduction in sperm count, motility and birth weight was observed [57]. Noteworthy is the fact that Scarano et al. [52] did not observe changes in the serum and testosterone levels or in prostate weight at a dose of $100 \mathrm{mg} / \mathrm{kg}$ bw, but these effects were noted at lower doses ( $\geq 10 \mathrm{mg} / \mathrm{kg} \mathrm{bw})$ [37].

In the subsequent dose range of $250-300 \mathrm{mg} / \mathrm{kg}$ bw, DBP given orally to pregnant rats, in addition to the symptoms listed above, also resulted in significant delayed testis descent, a decrease in the seminal vesicles, epididymides and Cowper's gland weight (exposure time: GD 10-19) [40], germ cell loss, testicular atrophy, hypospadias, absent or ectopic testes (exposure time: GD 3-PND 20) [56], retained thoracic nipples (exposure time: GD 12-21) [44], and a reduced testosterone production (exposure time: GD 8-18) [49].

In a 2-generation study where DBP was given via food at a dose of $256 \mathrm{mg} / \mathrm{kg} \mathrm{bw} / \mathrm{day}$, degeneration of the seminiferous tubules, incompletely developed or absent epididymis, and atrophic changes in the testes were observed [23,60]. When given orally to pregnant females at GD 7-15, at a dose of $500 \mathrm{mg} / \mathrm{kg}$ bw, DBP resulted in increased resorptions of the implanted embryos [38], and at GD 12-21 decreased body weight was observed in 1 female after 18 days of pregnancy, and a birth of dead/exhausted pups was noted [44]. When the exposure time changed (GD 3-PND 20), a reduction in uterine weight was observed [56]. A significant increase in the number of dead fetuses was observed when exposure to DBP covered a period of GD 1-PND 21 [57].
In a 2-generation study conducted on females treated orally with $500 \mathrm{mg} / \mathrm{kg}$ bw, the following changes were observed in F0 females: a decrease in the number of litters and the serum progesterone level, coupled with an increased estradiol production; and in F1 females: decreased fertility [58]. When the dams were exposed to $500 \mathrm{mg} / \mathrm{kg}$ bw of DBP orally, F1 males had additional symptoms which were not described above, such as a decreased sperm production, degeneration of the seminiferous epithelium (exposure time: GD 10-20) [41], obstruction of testicular fluid flow due to malformed epididymides (exposure time: GD 12-21) [33], cryptorchidism (exposure time: GD 13.5-20.5/21.5) [36], hypospadias, immature Sertoli cells (exposure time: GD 13-21) [39], the absence of the prostate gland (exposure time: GD 3-PND 20) [56], partially developed or even absent epididymides, seminal vesicles, ventral prostate, and vas deferens, a decreased weight of the ventral and dorsolateral prostates, and the levator ani-bulbocavernosus muscle, intersticial cell adenoma, focal intersticial cell hyperplasia (exposure time: GD 12-21) [44-46], Leydig cell proliferation (exposure time: GD 14.5-PND 6) [51], a decreased androstenedione level (exposure time: GD 12-21) [47], and adenomas (exposure time: GD 12-21) [48].

In a 2-generation study, the F1 males exposed to $509 \mathrm{mg} / \mathrm{kg}$ bw/day of DBP via food also developed some atrophic changes in the testes, and had an underdeveloped penis or foreskin, besides the adverse effects which were also observed in lower doses [23,60]. Detailed symptoms which were noted during these studies are presented in Table 2.

The dams treated orally with $630 \mathrm{mg} / \mathrm{kg}$ bw had also a decreased fetal weight and an increased incidence of implantation loss (exposure time: GD 7-15) [38]. A slightly higher dose (661 mg/kg bw) of DBP given at GD 11-21 caused a higher incidence of fetuses malformations (cleft palate, fusion of the sternebrae) [50].

When the dose of DBP given orally to pregnant rats on GD 7-9 increased to $750 \mathrm{mg} / \mathrm{kg}$ bw, an additional defor- 
mity of the vertebratal column in the thoracic and cervical regions of the ribs was observed [31]. When the exposure time changed from 15 GD to 21 PND, a reduction in the prolactin cells in both sexes, an increased relative weight of the pituitary in both sexes, and hypoplasia of the nipples in males were noted [55].

Treating pregnant Sprague-Dawley rats with $1000 \mathrm{mg} / \mathrm{kg} \mathrm{bw}$ of DBP orally at GD 12-20 resulted in the complete resorption of implanted embryos and 2 maternal deaths [38].

When given orally to pregnant Sprague-Dawley rats at a dose of $1500 \mathrm{mg} / \mathrm{kg}$ bw after GD 8, DBP resulted in deformations of the cervical vertebrae. In the fetuses treated in utero on GD 9, deformations of the ribs and dilatation of the renal pelvis were also noted [29].

Treating pregnant females with DBP at a dose $2000 \mathrm{mg} / \mathrm{kg}$ bw orally on GD 14 resulted in a reduced number of live fetuses besides the previously mentioned adverse toxic effects [28]. A decreased anogenital distance and a lower testosterone level occurred at the lowest dose of $10 \mathrm{mg} / \mathrm{kg}$ bw given from GD 14 until delivery [37]. These effects were observed in practically all the studies related to the observation of utero exposure to DBP [32,34-36,40,42$48,50,51,54,56,57,59]$. There is only one alluring report where the authors did not notice changes in the serum and testicular testosterone levels, in which pregnant rats were treated orally with $100 \mathrm{mg} \mathrm{DBP} / \mathrm{kg}$ bw at GD 12PND 21 [52]. One of the most common symptoms in F1 males was reduced testicular weight which appeared when DBP was given at a dose of $100 \mathrm{mg} / \mathrm{kg}$ bw at GD 1221 [42]. Leydig cells abnormalities were evident (clusters, aggregation, hyperplasia), starting from a dose of $100 \mathrm{mg} / \mathrm{kg}$ bw/day, and the same applied to multinucleated gonocytes and multinucleated germinative cells, regardless of the exposure time (GD 12-21, GD 13.5-20.5/21.5, GD 12-PND 21, and GD 12-19) [35,36,43,53].

In addition to changes related to the testes, epididymides and sperm parameters, DBP was found to cause increased liver and kidney weight, starting from a dose of
$500 \mathrm{mg} / \mathrm{kg}$ bw $[23,58,60]$. However, in a study by Mylchreest et al. [56], the authors treated pregnant CD rats with DBP at a dose of $750 \mathrm{mg} / \mathrm{kg}$ bw/day at GD 3-PND 20, and noted a reduction in the average kidney weight.

It is also worth paying attention to the maternal effects caused by DBP which started to occur from a dose of $\geq 80 \mathrm{mg} / \mathrm{kg}$ bw given before gestation, and resulted in a decreased number of live pups per litter and a lower live pup weight $[23,60]$. However, DBP treatment at a dose of $500 \mathrm{mg} / \mathrm{kg}$ bw (exposure time: GD 1-PND 21) resulted in an increased number of dead fetuses [57], and exposure to DBP at GD 7-15 at a dose of $630 \mathrm{mg} / \mathrm{kg}$ bw caused the same effect [38]. The fact that there were no changes in the frequency and length of the estrous cycle in F1 females even at the highest dose (794 mg/kg bw/day) seems quite interesting $[23,60]$. The observation made by Ema et al. [50] who treated pregnant rats with DBP at a dose of $661 \mathrm{mg} / \mathrm{kg}$ bw at GD 11-21, and noted that the number of live fetuses, and the incidence of postimplantation loss, dead fetuses and resorptions, did not differ from controls, also appears alluring.

Fetal malformations started to appear when DBP was used at a dose of $661 \mathrm{mg} / \mathrm{kg}$ bw/day (exposure time: GD 11-21) and mainly cleft palate and fusion of the sternebrae were observed [50]. The same malformations were noted at a dose of $750 \mathrm{mg} / \mathrm{kg}$ bw given at GD 13-15 [32], while at a dose of $750 \mathrm{mg} / \mathrm{kg}$ bw used at GD 7-15, only cleft palate was found to occur [38]. A single treatment with DBP at a dose of $1000 \mathrm{mg} / \mathrm{kg}$ bw on GD 14 resulted in the increased incidence of skeletal malformations [28].

A 2-generation study conducted on Sprague-Dawley rats which were given DBP via food resulted in adverse effects only at the highest dose (1000 mg/kg bw/day) [59], which are described in detail in Table 2.

The embryotoxic effects of DBP on laboratory animals include mainly an increase in fetal resorption and a decrease in live births $[23,28,38,56,57,60]$. The teratogenic effects 
of DBP also manifest as skeletal malformations in fetuses (e.g., cleft palate, deformations of the cervical vertebrae, ribs, thoracic vertebrae, and sternebrae fusion) [28,29,31,50], malformations of male gonads (e.g., cryptorchidism or hypospadias) $[23,36,39,44-46,50,51,56,57,60]$, and other genital effects $[23,33,35,37,40-46,48,51,55-57,59,60]$.

\section{CONCLUSIONS}

The review of the literature was prepared due to increasing reports concerning the reproductive and developmental toxicity of DBP on laboratory animals.

The results of the presented studies suggest that the most common testicular effects of oral exposure to DBP in laboratory animals were reduced fertility, atrophic changes in male gonads, degenerative changes in the epididymis, as well as a reduction in sperm count and motility, reduced sperm quality, decreased testicular weight, delayed spermatogenesis, Leydig cell aggregation, impaired Sertoli cell maturation, and significant inhibitions of testicular enzymes.

On the basis of the literature data, it is clearly demonstrated that DBP shows the anti-androgenic effects while there are also reports confirming its weak estrogenic effect.

Based on the collected data, it can be assumed that DBP has a non-linear dose-response relationship which is typical for endocrine disruptors where stronger physiological responses can be observed at lower doses than at higher ones. Such a scenario is contrary to the typical toxicological concept assuming a linear relationship between the chemical dose and the effect, better known as "the dose makes the poison" principle. In the case of endocrine disruptors, there probably exist many physiological explanations of this phenomenon, but additional studies are needed for DBP to fully understand the mechanism.

Based on the presented results, the embryotoxic effects of DBP on laboratory animals include an increase in fetal resorption and a decrease in live births. The teratogenic effects of DBP also manifest as skeletal malformations in fetuses which include, e.g., cleft palate, deformations of the cervical vertebrae, ribs, thoracic vertebrae and the sternebrae fusion, dilatation of the renal pelvis, deformations of the vertebratal column, changes in male gonads, such as cryptorchidism or hypospadias, and other testicular abnormalities.

\section{ACKNOWLEDGMENTS}

The authors would like to thank Joanna Jurewicz, Ph.D., Professor of the Nofer Institute of Occupational Medicine, Head of the Department of Chemical Safety, for her knowledge and support that improved the manuscript.

\section{REFERENCES}

1. European Chemicals Agency [Internet]. Helsinki: The Agency; 2019 [cited 2019 Oct 3]. Registration dossier. Available from: https://echa.europa.eu/registration-dossier/-/registereddossier/14862.

2. European Commission [Internet]. Brussels: The Commission [cited 2019 Oct 7]. Commission Delegated Directive (EU) 2015/863 of 31 March 2015 amending Annex II to Directive 2011/65/EU of the European Parliament and of the Council as regards the list of restricted substances. Available from: https://ec.europa.eu/transparency/regdoc/rep/3/2015/EN/32015-2067-EN-F1-1.PDF.

3. IHS Markit [Internet]. London: The Company [cited 2019 Oct 7]. CEH: Plasticizers (Report) May 2018. Available from: https://ihsmarkit.com/products/plasticizers-chemical-economics-handbook.html.

4. European Chemicals Agency [Internet]. Helsinki: The Agency; 2008 [cited 2020 Mar 9]. Registration dossier (DBP). Available from: https://echa.europa.eu/pl/registration-dossier/-/reg istered-dossier/14862.

5. European Chemicals Agency [Internet]. Helsinki: The Agency; 2019 [cited 2020 Jul 27]. Support document to the opinion of the Member State Committee for identification of dibutyl phthalate (DBP) as a substance of very high concern because 
of its endocrine disrupting properties which cause probable serious effects to human health and the environment which give rise to an equivalent level of concern to those of CMR and PBT/vPvB substances. Available from: https://echa.europa.eu/ documents/10162/e4edaefa-84a4-4972-89f0-470cd64bc949.

6. European Commission [Internet]. Brussels: The Commission; 2019 [cited 2019 Dec 4]. What are endocrine disruptors? 2019. Available from: https://ec.europa.eu/environment/chemicals/endocrine/definitions/endodis_en.htm.

7. Regulation (EC) No 1907/2006 of the European Parliament and of the Council concerning the Registration, Evaluation, Authorisation and Restriction of Chemicals (REACH), establishing a European Chemicals Agency, amending Directive 1999/45/EC and repealing Council Regulation (EEC) No 793/93 and Commission Regulation (EC) No 1488/94 as well as Council Directive 76/769/EEC and Commission Directives 91/155/EEC, 93/67/EEC, 93/105/EC and 2000/21/ EC. OJ EU L396/1.

8. Regulation (EC) No 1272/2008 of the European Parliament and of the Council on classification, labelling and packaging of substances and mixtures, amending and repealing Directive 67/548/EEC and 1999/45/EC and amending Regulation No 1907/2006. OJ EU L353/1.

9. Thomas JA. Reproductive and developmental effects of phthalates. Int J Toxicol. 1999;18(6):449-55.

10. Williams DJ. Toxicity reviev of di-n-butyl phthalate [Internet]. Bethesda: Memorandum; 2010 [cited 2020 Jul22]. Available from: https://www.cpsc.gov/s3fs-public/ToxicityReview OfDBP.pdf.

11. Kay VR, Bloom MS, Foster WG. Reproductive and developmental effects of phthalate diesters in males. Crit Rev Toxicol. 2014;44(6);467-98, https://doi.org/10.3109/10408444.2013. 875983.

12. Asghari MH, Saeidnia S, Abdollahi M. A review on the biochemical and molecular mechanisms of phthalate-induced toxicity in various organs with a focus on the reproductive system. Int J Pharm. 2015;11:95-105, https://doi.org/10.3923/ ijp.2015.95.105.
13. Kim HS, Kim TS, Shin JH, Moon HJ, Kang IH, Kim IY, et al. Neonatal exposure to di(n-butyl) phthalate (DBP) alters male reproductive-tract development. J Toxicol Environ Health A. 2004;67(23-24):2045-60, https://doi.org/10.1080/ 15287390490514859 .

14. Farombi EO, Abarikwu SO, Adedara IA, Oyeyemi MO. Curcumin and kolaviron ameliorate di-n-butylphthalate-induced testicular damage in rats. Basic Clin Pharmacol Toxicol. 2007;100(1):43-8, https://doi.org/10.1111/j.1742-7843.2007. 00005.x.

15. Zhou D, Wang H, Zhang J, Gao X, Zhao W, Zheng Y. Dinn-butyl phthalate (DBP) exposure induces oxidative damage in testes of adult rats. Sys Biol Repr Med. 2010;56(6):413-9, https://doi.org/10.3109/19396368.2010.509902.

16. Aly HAA, Hassan MH, El-Beshbishy HA, Alahdal AM, Osman AMM. Dibutyl phthalate induces oxidative stress and impairs spermatogenesis in adult rats. Toxicol Ind Health. 2016;23(8):1467-77, https://doi.org/10.1177/0748233 714566877.

17. Srivastava SP, Srivastava S, Saxena DK, Chandra SV, Seth PK. Testicular effects of di-n-butyl phthalate (DBP): biochemical and histopathological alterations. Arch Toxicol. 1990; 64(2):148-52, https://doi.org/10.1007/bf01974401.

18. Yin L, Yan L, He B, Fang Y, Liu X, Duan C, et al The toxic effects of a plasticizer, dibutyl phthalate, on rat testis. Int J Clon Exp Pathol. 2016;9(11):11246-53.

19. Mitsuhashi M, Morimura K, Wanibuchi H, Hayashi S, Kiyota A, Wada S, et al. Di-n-butyl phthalate is toxic to the male reproductive system and its toxicity is enhanced by thioacetamide induced liver injury. J Toxicol Pathol. 2004;17:177-85, https://doi.org/10.1293/tox.17.177.

20. Chen X, An H, Ao L, Sun L, Liu W, Zhou Z, et al. The combined toxicity of dibutyl phthalate and benzo(a)pyrene on the reproductive system of male Sprague Dawley rats in vivo. J Hazard Mater. 2011;186(1):835-41, https://doi.org/ 10.1016/j.jhazmat.2010.11.078.

21. Kwack SJ, Kim KB, Kim HS, Lee BM. Comparative toxicological evaluation of phthalate diesters and metabolites 
in Sprague-Dawley male rats for risk assessment. Toxicol Environ Health A. 2009;72(21-22):1446-54, https://doi.org/ 10.1080/15287390903212923.

22. Tsutsumi T, Ichihara T, Kawabe M, Yoshino H, Asamoto M, Suzuki S, et al. Renal toxicity induced by folic acid is associated with the enhancement of male reproductive toxicity of di(nbutyl) phthalate in rats. Reprod Toxicol. 2004;18(1):3542, https://doi.org/10.1016/j.reprotox.2003.08.004.

23. Marsman DS. NTP Technical Report on toxicity studies of dibutyl phthalate (CAS No. 84-74-2). Administered in feed to F344/N rats and $\mathrm{B} 6 \mathrm{C} 3 \mathrm{~F} 1$ mice [Internet]. NIH Publication; 1995 [cited 2019 Oct 31]. Available from: https://ntp. niehs.nih.gov/ntp/htdocs/ST_rpts/tox030.pdf.

24. Moody S, Goh H, Bielanowicz A, Rippon P, Loveland K, Itman C. Prepubertal mouse testis growth and maturation and androgen production are acutely sensitive to di-n-butyl phthalate. Endocrinology. 2013;154(9):3460-75, https://doi. org/10.1210/en.2012-2227.

25. Oda SS, Waheeb RS. Ginger attenuated di(n-butyl) phthalate-induced reproductive toxicity in pubertal male rabbits. World Rabbit Sci. 2017;25:387-98, https://doi.org/10.4995/ wrs.2017.7466.

26. Higuchi TT, Palmer JS, Gray LE Jr, Veeramachaneni DNR. Effects of dibutyl phthalate in male rabbits following in utero adolescent, or postbuertal exposure. Toxicol Sci. 2003;72(2):301-13, https://doi.org/10.1093/toxsci/kfg036.

27. Hallmark N, Walker M, McKinnell C, Mahood IK, Scott H, Bayne R, et al. Effects of monobutyl and di(n-butyl) phthalate in vitro on steroidogenesis and Leydig cell aggregation in fetal testis explants from the rat: comparison with effects in vivo in the fetal rat and neonatal marmoset and in vitro in the human. Environ Health Perspect. 2007;115(3):390-6, https://doi.org/10.1289/ehp.9490.

28. Saillenfait AM, Payan JP, Fabry JP, Beydon D, Langonne I, Gallissot F, et al. Assessment of the developmental toxicity, metabolism and placental transfer of di-n-butyl phthalate administered to pregnant rats. Toxicol Sci. 1998;45(2):21224, https://doi.org/10.1006/toxs.1998.2518.
29. Ema M, Harazano A, Miyawaki E, Ogawa Y. Developmental effects of di-n-butyl phthalate after a single administration in rats. J Appl Toxicol. 1997;17(4):223-9, https:// doi.org/10.1002/(SICI)1099-1263(199707)17:4<223::AIDJAT433>3.0.CO;2-H.

30. Spade DJ, Hall SJ, Wilson S, Boekelheide K. Di-n-butyl phthalate induces multinucleated germ cells in the rat fetal testis through a nonproliferative mechanism. Biol Repr. 2015;93(5):110, http://doi.org./10.1095/biolreprod.115. 131615.

31. Ema M, Amano H, Ogawa Y. Characterization of the developmental toxicity of di-n-butyl phthalate in rats. Toxicology. 1994;86(3):163-74, https://doi.org/10.1016/0300-483x(94) 90002-7.

32. Giribabu N, Sainath SB, Sreenivasula Reedy P. Prenatal din-butyl phthalate exposure alters reproductive functions at adulthood in male rats. Environ Toxicol. 2014;29(5):534-44, https://doi.org/10.1002/tox.21779.

33. Barlow NJ, Foster PM. Pathogenesis of male reproductive tract lesions from gestation through adulthood following in utero exposure to di(n-butyl) phthalate. Toxicol Pathol. 2003;31(4):397-410, https://doi.org/10.1080/0192623 0390202335 .

34. Lehmann KP, Phillips S, Sar M, Foster PM, Gaido KW. Dose-dependent alterations in gene expression and testosterone synthesis in the fetal testes of male rats exposed to di(n-butyl) phthalate. Toxicol Sci. 2004;81(1):60-8, https:// doi.org/10.1093/toxsci/kfh169.

35. Struve MF, Gaido KW, Hensley JB, Lehmann KP, Ross SM, Sochaski MA, et al. Reproductive toxicity and pharmacokinetics of di-n-butyl phthalate (DBP) following dietary exposure of pregnant rats. Birth Defects B Dev Reprod Toxicol. 2009;86(4):345-54, https://doi.org/10.1002/bdrb.20199.

36. Mahood IK, Scott HM, Brown R, Hallmark N, Walker M, Sharpe RM. In utero exposure to di(n-butyl) phthalate and testicular dysgenesis: Comparison of fetal and adult end points and their dose sensitivity. Environ Health Persp. 2007;115:55-61, https://doi.org/10.1289/ehp.9366. 
37. Ahmad R, Gautam AK, Verma Y, Sedha S, Kumar S. Effects of in utero di-butyl phthalate and butyl benzyl phthalate exposure on offspring development and male reproduction of rat. Environ Sci Pollut Res. 2014;21(4):3156-65, https://doi. org/10.1007/s11356-013-2281-x.

38. Ema M, Amano H, Itami T, Kawasaki H. Teratogenic evaluation of di-n-butyl phthalate in rats. Toxicol Lett. 1993;69(2):193-203, https://doi.org/10.1016/0378-4274(93) 90104-6.

39. Fisher JS, Macpherson S, Marchetti N, Sharpe RM. Human "testicular dysgenesis syndrome": a possible model using inutero exposure of the rat to dibutyl phthalate. Hum Reprod. 2003;18(7):1383-94, https://doi.org/10.1093/humrep/deg273.

40. Kim T, Shin J, Lee S, Moon H, Kang I, Kim I, et al. Effects of in utero exposure of disethylstilbestrol and dibutyl phthalate on the testis descent in rat offspring. Toxicologist. 2004;78:118.

41. Kleymenova E, Swanson C, Boekelheide K, Gaido KW. Exposure in utero to di(n-butyl) phthalate alters the vimentin cytoskeleton of fetal rat Sertoli cells and disrupts Sertoli Cell-gonocyte contact. Bioll Reprod. 2005;73(3):482-90, https://doi.org/10.1095/biolreprod.104.037184.

42. Shirai M, Wakui S, Wempe MF, Mutou T, Oyama N, Motohashi M, et al. Male Sprague-Dawley rats exposed to in utero di(n-butyl) phthalate: Dose dependent anmd agerelated morphological changes in Leydig cell smooth endoplasmic reticulum. Toxicol Path. 2013;41(7):984-91, https:// doi.org/10.1177/0192623312474725.

43. Wakui S, Takahashi H, Mutou T, Shirai M, Jutabha P, Anzai N, et al. Atypical Leydig cells hyperplasia in adult rats with low $\mathrm{T}$ and high LH induced by prenatal di(n-butyl) phthalate exposure. Toxicol Path. 2013;41(3):480-6, https:// doi.org/10.1177/0192623312457272.

44. Mylchreest E, Sar M, Cattley RC, Foster PM. Disruption of androgen-regulated male reproductive development by di(n-butyl) phthalate during late gestation in rats is different from flutamide. Toxicol Appl Pharmacol. 1999;156(2):81-95, https://doi.org/10.1006/taap.1999.8643.
45. Mylchreest E, Wallace DG, Cattley RC, Foster PMD. Dosedependent alteration in androgen-regulated male reproductive development in rats exposed to di(n-butyl)phthalate during late gestation. Toxicol Sci. 2000;55(1):413-51, https:// doi.org/10.1093/toxsci/55.1.143.

46. Kavlock R, Boekelheideb K, Chapine R, Cunninghame M, Faustmand E, Fostere P, et al. NTP Center for the Evaluation of Risks to Human Reproduction: phthalates expert panel report on the reproductive and developmental toxicity of di-n-butyl phthalate. Reprod Toxicol. 2002;16:489-527, https://doi.org/10.1016/S0890-6238(02)00033-3.

47. Schultz VD, Philips S, Sar M, Foster PM, Gaido KW. Altered gene profiles in fetal rat testes in utero exposure to di(n-butyl) phthalate. Toxicol Sci. 2001;64(2):233-42, https:// doi.org/10.1093/toxsci/64.2.233.

48. Mylchreest E, Sar M, Wallace DG, Foster PM. Fetal testosterone insufficiency and abnormal proliferation of Leydig cells and gonocytes in rats exposed to di(n-butyl) phthalate. Repro Toxicol. 2002;16(1):19-28, https://doi.org/10.1016/ s0890-6238(01)00201-5.

49. Howdeshell KL, Wilson VS, Furr J, Lambright CR, Rider CV, Blystone $\mathrm{CR}$, et al. A mixture of five phthalate esters inhibits fetal testicular testosterone production in the Sprague-Dawley rat in a cumulative, dose-additive manner. Toxicol Sci. 2008;105(1):153-65, https://doi.org/10.1093/toxsci/kfn077.

50. Ema M, Miyawaki E, Kawashima K. Further evaluation of developmental toxicity of di-n-butyl phthalate following administration during late pregnancy of rats. Toxicol Lett. 1998;98(1-2):87-93, https://doi.org/10.1016/s0378-4274(98) 00107-6.

51. Ivell R, Heng K, Nicholson H, Anand-Ivell R. Brief maternal exposure of rats to the xenobiotics dibutyl phthalate or diethylstilbestrol alters adult-type Leydig cell development in male offspring. Asian J Androl. 2013;15(2):261-8, https:// doi.org/10.1038/aja.2012.138.

52. Scarano WR, Toledo FC, Guerra MT, de Campos SG, Júnior LA, Felisbino SL, et al. Long-term effects of developmental exposure to di-n-butyl-phthalate (DBP) on rat prostate: 
Proliferative and inflammatory disorders and a possible role of androgens. Toxicol. 2009;262(3):215-23, https://doi.org/ 10.1016/j.tox.2009.06.011.

53. Scarano WR, Toledo FC, Guerra MT, Pinheiro PF, Domeniconi RF, Felisbino SL, et al. Functional and morphological reproductive aspects in male rats exposed to di-n-butyl phthalate (DBP) in utero and during lactation. J Toxicol Environ Health Part A. 2010;73(13-14):972-84, https://doi. org/10.1080/15287391003751760.

54. Peixoto AR, Santos TM, Brandt JZ, Delella FK, Gonçalves BF, Campos SG, et al. Gestational and lactational exposition to Di-N-butyl-phthalate (DBP) increases inflammation and preneoplastic lesions in prostate of Wistar rats after carcinogenic N-methyl-N-nitrosourea (MNU) plus testosterone protocol. Environ Toxicol. 2016;31(10):1185-95, https://doi.org/10.1002/tox.22126.

55. Lee KY, Shibutani M, Takagi H, Kato N, Shu T, Unemaya C, et al. Diverse developmental toxicity of di-n-butyl phthalate in both sexes of rat offspring after maternal exposure during the period from late gestation through lactation. Toxicol. 2004;203 (1-3):221-38, https://doi.org/10.1016/j.tox.2004.06.013.

56. Mylchreest E, Cattley RC, Foster PM. Male reproductive tract malformations in rats following geastational and lactational exposure to di(n-butyl) phthalate: an antiandrogenic mechanism? Toxicol Sci. 1998;43(1):47-60, https://doi. org/10.1006/toxs.1998.2436.

57. Zhang Y, Jiang X, Chen B. Reproductive and developmental toxicity in F1 Sprague-Dawley male rats exposed to din-butyl phthalate in utero and during lactation and determination of its NOAEL. Reprod Toxicol. 2004;18(5):669-76, https://doi.org/10.1016/j.reprotox.2004.04.009.

58. Gray LE Jr, Laskey J, Ostby J. Chronic di-n-butyl phthalate exposure in rats reduces fertility and alters ovarian function during pregnancy in female Long Evans hooded rats. Toxicol Sci. 2006;93(1):189-95, https://doi.org/10.1093/toxsci/kfl035.

59. Wolfe GW, Patel RV. Dibutyl phthalate: Multigenerational reproductive assessment by continuous breeding when administered to Sprague-Dawley rats in the diet [Internet]. NIEHS Publication; 2002 [cited 2019 Nov 19] Available from: https://ntrl.ntis.gov/NTRL/dashboard/searchResults. xhtml?searchQuery=PB2003100647.

60. Wine RN, Hommel Barnes L, Gulati DK, Chapin RE. Reproductive toxicity of di-n-butylphthalate in a continuous breeding protocol in a Sprague-Dawley rats. Environ Health Perspect. 1997;105(1):102-7, https://doi.org/10.1289/ ehp. 97105102 .

This work is available in Open Access model and licensed under a Creative Commons Attribution-NonCommercial 3.0 Poland License - http://creativecommons.org/ licenses/by-nc/3.0/pl/deed.en. 